\title{
Paleomagnetism of a lateritic paleoweathering horizon and overlying Paleoproterozoic red beds from South Africa: Implications for the Kaapvaal apparent polar wander path and a confirmation of atmospheric oxygen enrichment
}

\author{
D. A. D. Evans ${ }^{1}$ \\ Tectonics Special Research Centre, University of Western Australia, Nedlands, Australia \\ N. J. Beukes \\ Department of Geology, Rand Afrikaans University, Johannesburg, South Africa \\ J. L. Kirschvink \\ Division of Geological and Planetary Sciences, California Institute of Technology, Pasadena, California, USA \\ Received 3 May 2000; revised 25 January 2002; accepted 30 January 2002; published 6 December 2002.
}

[1] The Olifantshoek Group in southern Africa contains Paleoproterozoic red beds that are exceptionally well preserved, lying unconformably atop a regionally extensive lateritic paleoweathering profile. We studied the basal unit of this succession, known as the Gamagara or Mapedi Formation, and the lateritized substrate (so-called "Drakenstein" or "Wolhaarkop" paleosol) on which it developed. Two ancient magnetic components are observed. One (INT), usually with a distributed unblocking spectrum between $300^{\circ}$ and $600^{\circ} \mathrm{C}$ but occasionally persisting to $>675^{\circ} \mathrm{C}$, is directed shallowly southward or northward. A mesoscale fold test at South Sishen Mine indicates that this component was acquired during deformation; similarity of the direction to previous results suggests that it was acquired at $\sim 1240 \mathrm{Ma}$, during early Namaqua orogenesis. Combining our INT results with existing data from the Namaqua eastern zone (NEZ), we calculate the NEZ pole at $\left(44.9^{\circ} \mathrm{N}, 021.5^{\circ} \mathrm{E}, K=\right.$ 23.2, $A_{95}=12.8^{\circ}, Q=5$ ). The most stable component from our data set (HIG), always persisting as a nonzero endpoint to demagnetization at $>665^{\circ}-680^{\circ} \mathrm{C}$, is observed in 32 samples from South Sishen and Beeshoek Mines. Directed moderately east-downward (Sishen) or west-upward (Beeshoek), this component predates the mesoscale fold at Sishen. More importantly, a conglomerate test at Beeshoek indicates that HIG was acquired prior to Paleoproterozoic deposition of the Gamagara/Mapedi Formation. The concordance between directions from the paleoweathering zone and immediately overlying red beds indicates that HIG is a primary magnetic remanence for the basal Gamagara/Mapedi (BGM) Formation. The dual-polarity BGM paleomagnetic pole $\left(02.2^{\circ} \mathrm{N}, 081.9^{\circ} \mathrm{E}, \mathrm{dp}=7.2^{\circ}, \mathrm{dm}=\right.$ $11.5^{\circ}, Q=6$ ) lies neatly between previous Kaapvaal poles with ages of $\sim 2220$ (Ongeluk lavas) and $2060 \mathrm{Ma}$ (Bushveld complex). Our data thus support recent correlations of the Gamagara/Mapedi Formation with pre-Bushveld sediments of the Pretoria Group. A preBushveld age for BGM is also consistent with its substantial distance from a new, albeit less reliable, paleomagnetic pole from the $\sim 1930$-Ma Hartley lavas, higher within the Olifantshoek succession $\left(12.5^{\circ} \mathrm{N}, 332.8^{\circ} \mathrm{E}, K=18.6, A_{95}=16.0^{\circ}, Q=3\right)$. Our conglomerate test at Beeshoek confirms previous allegations that the intense hematitization observed in the Drakenstein-Wolhaarkop paleosol occurred during Paleoproterozoic weathering under a highly oxygenated atmosphere. INDEX TERMS: 0325 Atmospheric Composition and Structure: Evolution of the atmosphere; 1525 Geomagnetism and Paleomagnetism: Paleomagnetism applied to tectonics (regional, global); 1527 Geomagnetism and Paleomagnetism: Paleomagnetism applied to geologic processes; 9619 Information Related to Geologic Time: Precambrian; KEYWORDS: paleomagnetism, Paleoproterozoic, South Africa, apparent polar wander paths, paleoatmosphere, lateritic paleosols \footnotetext{
Haven, Connecticut, USA.

${ }^{1}$ Now at Department of Geology and Geophysics, Yale University, New 
Citation: Evans, D. A. D., N. J. Beukes, and J. L. Kirschvink, Paleomagnetism of a lateritic paleoweathering horizon and overlying Paleoproterozoic red beds from South Africa: Implications for the Kaapvaal apparent polar wander path and a confirmation of atmospheric oxygen enrichment, J. Geophys. Res., 107(B12), 2326, doi:10.1029/2001JB000432, 2002.

\section{Introduction}

[2] The Kaapvaal craton in southern Africa contains an extraordinary and well preserved Neoarchean to Paleoproterozoic geological record, including some of the oldest examples of red soils and sediments that indicate an oxidizing atmosphere and terrestrial biosphere on Earth [Gutzmer and Beukes, 1998]. In the Griqualand West area of the Northern Cape Province, the earliest red beds are found within the Gamagara/Mapedi Formation, lying atop a regional unconformity [Beukes and Smit, 1987] (Figure 1). Below this unconformity is an extensive lateritic paleosol that now hosts a variety of $\mathrm{Fe}$ and $\mathrm{Mn}$ ore deposits in the region [Van Schalkwyk and Beukes, 1986; Grobbelaar and Beukes, 1986]. Where intersected in drillcores, the hematitic paleoweathering profile is known locally as the Drakenstein [Wiggering and Beukes, 1990] or Wolhaarkop [Holland and Beukes, 1990] paleosol.

[3] Under the assumption that the Wolhaarkop hematite enrichment occurred prior to deposition of the red beds rather than from subsequent infiltration of oxidized fluids, Holland and Beukes [1990] used the chemistry of the paleosol to calculate oxidation states of the Paleoproterozoic atmosphere. The Drakenstein-Wolhaarkop paleoweathering zone has since been recognized as the oldest fully lateritic paleosol and thus can provide minimum constraints for both the amount and timing of atmospheric oxygen enrichment [Rye and Holland, 1998], possibly in the aftermath of a "Snowball Earth" glaciation [Evans et al., 1997; Kirschvink et al., 2000]. Supporting the assumption of an original hematitization within the red beds, the Doornfontein Conglomerate Member of the Gamagara Formation contains clasts of material derived from the paleosol-enriched iron ore [Van Schalkwyk and Beukes, 1986]. The present study provides additional, independent constraints on the timing of hematitization within the paleosol and the overlying red beds, using paleomagnetism.

\section{Regional Geology}

[4] Mild warping of the Kaapvaal craton lithosphere has separated the Transvaal Supergroup into two distinct domains (Figure 1). In the eastern domain, the Pretoria Group contains a basal clastic succession with several possible glaciogenic levels [Bekker et al., 1999] followed by the Hekpoort volcanic succession, which is unconformably overlain by red beds of the Dwalheuwel Formation and succeeding siliciclastic formations of the upper Pretoria Group [Eriksson and Reczko, 1995]. This entire succession is intruded by the Bushveld Complex at $\sim 2060 \mathrm{Ma}$ [Walraven et al., 1990]. In the western domain or Griqualand West region, the Postmasburg Group comprises a basal glaciogenic unit followed immediately by the Ongeluk flood basalt, and succeeded further by bandediron formation, sedimentary Mn-formation, and local carbonate [see Kirschvink et al., 2000]. Following this is the sub-Gamagara/Mapedi unconformity with associated Drakenstein and Wolhaarkop paleosols [Beukes and Smit, 1987].
In addition to the regional hematitic paleoweathering horizon developed below this unconformity, lateritic features are locally found within the Gamagara Formation, indicating repeated episodes of Paleoproterozoic emergence and soil development [Gutzmer and Beukes, 1998].

[5] Recent detailed stratigraphic studies across the Griqualand West region have documented another unconformity separating this succession from the overlying Hartley lavas and higher quartzites of the upper Olifantshoek Supergroup [Beukes et al., 1999] (Figures 1 and 2). The Hartley lavas have yielded a U-Pb zircon evaporation age of $1928 \pm$ $4 \mathrm{Ma}$ [Cornell et al., 1998], providing an absolute minimum age constraint on the Gamagara/Mapedi Formation and the Drakenstein-Wolhaarkop paleosol, but recent correlations between this unconformity and the sub-Dwalheuwel unconformity within the Pretoria Group suggest that these lowest strata in the Olifantshoek Supergroup could be older than the $\sim 2060$ Ma Bushveld complex [Beukes et al., 2002] (Figure 1). We will show below how our paleomagnetic data further support a pre-Bushveld age for the Gamagara/ Mapedi Formation.

[6] A maximum age limit for the Gamagara/Mapedi Formation has traditionally been based upon numerous $\sim 2220$ Ma determinations from the unconformably underlying Ongeluk and Hekpoort lavas within the Postmasburg and Pretoria Groups, respectively [Cornell et al., 1996; see also Rye and Holland, 1998]. Possible indications of a substantially older age for the Ongeluk-Hekpoort volcanism, however, have arisen from a recent $\mathrm{Pb} / \mathrm{Pb}$ determination of 2394 $\pm 26 \mathrm{Ma}$ on the conformably overlying Mooidraai Dolomite [Bau et al., 1999]. According to that interpretation, the 2220-Ma ages from the Ongeluk-Hekpoort lavas would date a secondary chloritization event. Wiggering and Beukes [1990] reported clear petrographic and geochemical evidence that the Drakenstein paleosol developed subsequent to this chloritization. We believe, therefore, that regardless of the disputed eruptive age for the Ongeluk lavas, the Gamagara/Mapedi Formation and Drakenstein-Wolhaarkop paleosol are younger than $\sim 2220 \mathrm{Ma}$. This interpretation is supported also by strongly ${ }^{13} \mathrm{C}$-enriched carbonates within the conformably overlying Lucknow Formation [Master et al., 1993; Buick et al., 1998], likely correlating with a globally recognized period of such enrichment between 2.22 and 2.06 Ga [Karhu and Holland, 1996].

[7] The Griqualand West region is the foreland to Everging deformation related to the $\sim 1800-1700$-Ma Kheis and/or 1250-1000-Ma Namaqua orogens [Stowe, 1983; Onstott et al., 1986a; Altermann and Hälbich, 1991; Grobbelaar et al., 1995; Moen, 1999]. We sampled through a part of the foreland characterized by broad, open, shallow folds, interrupted by a single thrust fault (Blackridge thrust [Beukes and Smit, 1987]) with local subordinate splays. All of our sample localities except one (HLO in the Hartley lavas) lie within the autochthonous footwall zone of this thrust. Concordance of paleomagnetic directions from the Ongeluk lavas above and below the Blackridge thrust [Evans et al., 1997] indicates no discernible rotation of 


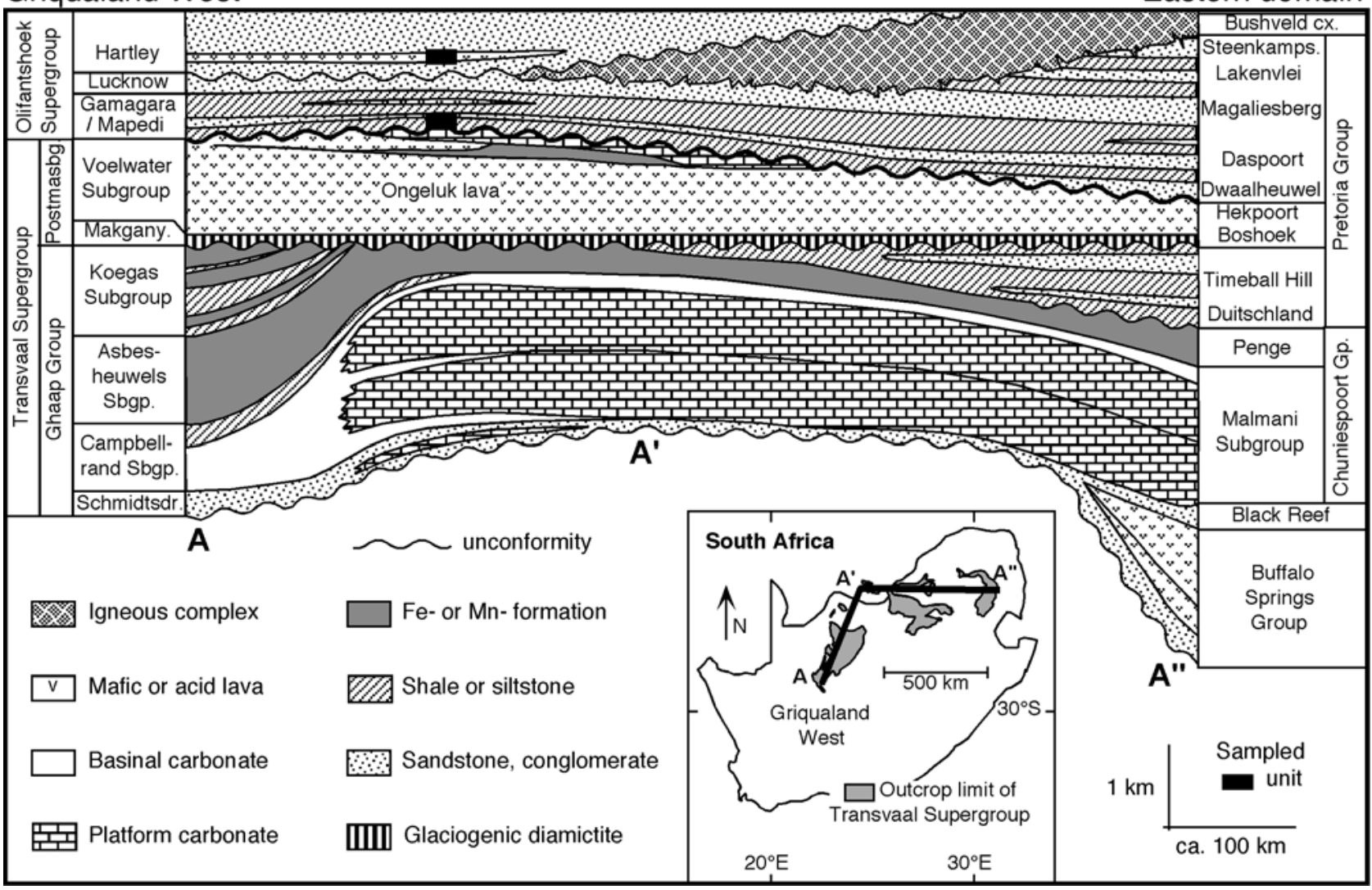

Figure 1. Schematic composite stratigraphic section across Kaapvaal (after Beukes [1986]; incorporating the new correlations of Beukes et al. [1999]). Note that the sub-Gamagara/Mapedi unconformity (in boldface) locally cuts down into Ghaap Group carbonates (not shown). Where we sampled beneath this unconformity (Sishen and Beeshoek), the substrates consist of Asbesheuwels Subgroup iron-formations.

the hanging wall relative to the autochthon since $\sim 2220$ Ma. The region has endured only low-grade metamorphism, with maximum temperatures of $110^{\circ}-170^{\circ} \mathrm{C}$ [Miyano and Beukes, 1984], except for moderate hydrothermal alteration in the immediate vicinity of thrust splays.

\section{Sampling and Analytical Techniques}

[8] We sampled lateritized iron ore and overlying Gamagara red beds at the Sishen, Beeshoek, and Rooinekke mines in the Griqualand West region (Figure 2). Most of the localities provided one or more field stability tests for our paleomagnetic directions: conglomerate tests on pebblesized clasts of iron ore at Sishen and Beeshoek, and a mesoscale fold test at Sishen. In addition, we sampled eight flowunits of the Hartley basalt at Olifantshoek.

[9] Samples were either drilled in the field or collected as blocks from which cylindrical cores of $2.5-\mathrm{cm}$ diameter were drilled in the lab. Orientation was achieved by a magnetic compass, and for most samples, a solar compass as well. Cores were trimmed into 2.4-cm long specimens for paleomagnetic analysis on a $2 \mathrm{G}$-Enterprises ${ }^{\circledR}$ RF-driven SQuID magnetometer housed at Caltech. One specimen per sample was analyzed. Strongly magnetized samples of the lateritic iron ore at Sishen were trimmed to approximately one-tenth the typical sample volume, and small pebble-sized ore clasts for the conglomerate tests were cut from oriented polished slabs of the blocks. Demagnetization steps varied slightly among the localities and lithologies studied, but generally followed a sequence of the naturalremanent magnetization (NRM), then alternating-field (AF) pretreatment to 10 or $20 \mathrm{mT}$, and then thermal demagnetization at decreasing intervals until specimen intensity dropped below noise level or, less commonly, spurious laboratory-induced magnetizations appeared. Each sample's magnetic components were deconvolved via least squares analysis [Kirschvink, 1980]. Susceptibility measurements, including anisotropy studies, were performed using a Bartington susceptibility bridge. A crushed and powdered aliquot of one sample per site was given an isothermalremanent magnetization (IRM) in stepwise pulses. All calculations of paleomagnetic poles assume an axial geocentric, dipolar geomagnetic field, with the Earth's paleoradius equal to that at present.

\section{Results}

[10] Depending on the sampled locality, our results range from straightforward to highly complex. The following discussion begins with the most clear-cut results and winds into more complicated data sets whose interpretation relies increasingly upon results of field tests from the more easily 


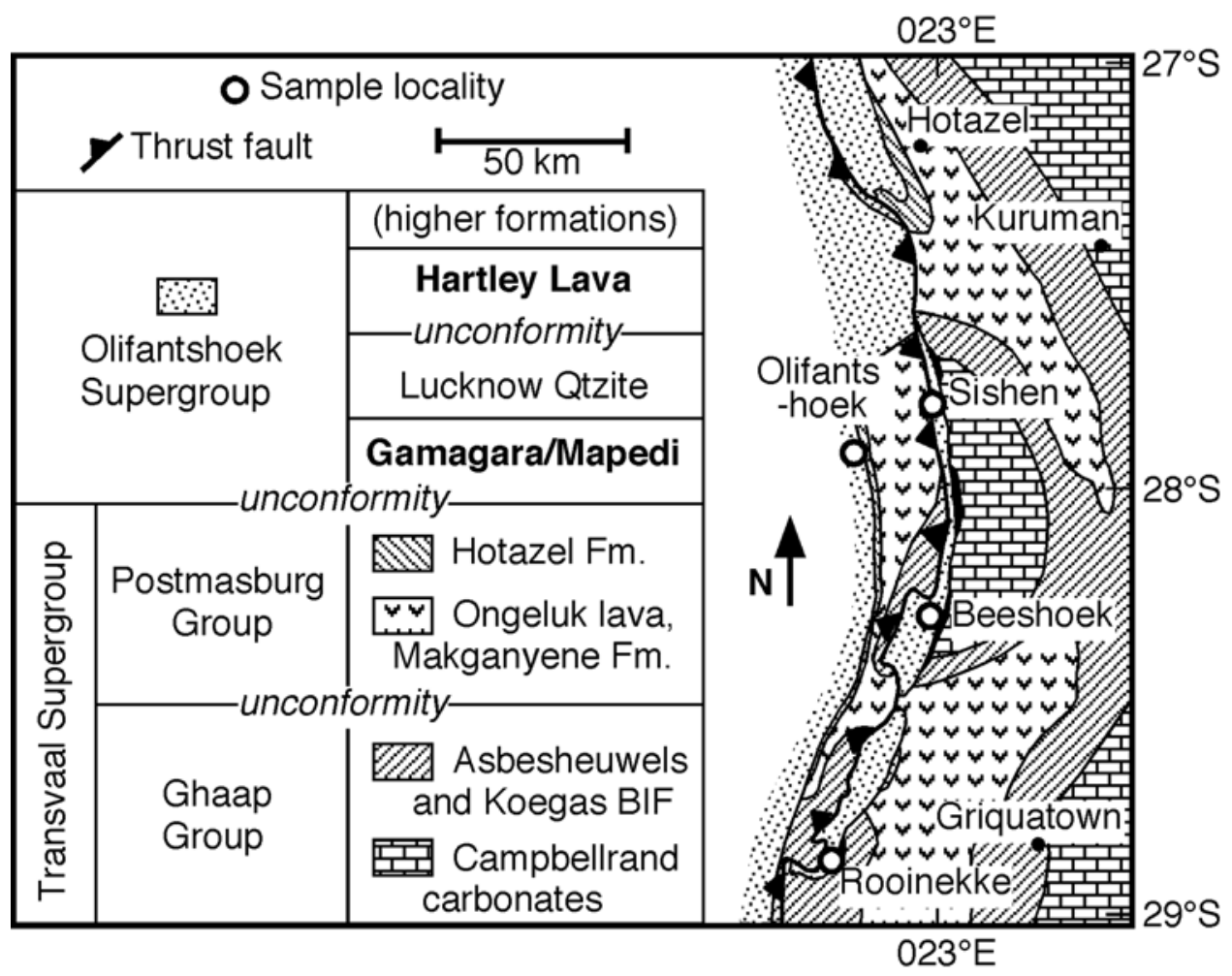

Figure 2. Simplified geological map and stratigraphic setting of Griqualand West, after Beukes and Smit [1987], but also incorporating the recently recognized unconformity within the lower Olifantshoek Supergroup [Beukes et al., 2002].

interpretable sites. Rock-magnetic characteristics of each site are presented in Table 1.

\subsection{South Sishen Mine (GFT, GSS)}

[11] From level 4 along the eastern face of the south Sishen Mine, 25 samples of Gamagara Formation red shales were collected. Thirteen (GFT) were taken from a single 5$\mathrm{cm}$-thick layer across a concentric monoclinal fold with northward vergence. Within this meter-scale structure, a steeply north-dipping limb punctuates the regional subhorizontal attitudes of Gamagara/Mapedi strata (Figure 3). Lack of penetrative deformation within beds precludes a soft-sediment origin for this fold. The other 12 South Sishen samples (GSS) were collected from subhorizontal beds at stratigraphic intervals of approximately $20 \mathrm{~cm}$. The total sampled stratigraphic interval is approximately $4 \mathrm{~m}$.

[12] Samples from the GFT fold test yielded three easily isolatable magnetic components (Figure 4). The first component to be removed ("LOW"), through the AF pretreatment and thermal steps to $250^{\circ}-300^{\circ} \mathrm{C}$, is directed steeply upward to the north in present coordinates. Upon restoration of bedding across the fold, dispersion of these directions increases dramatically, indicating a postfold remanence (Figure 5a). The LOW direction in a single specimen, specimen 6 from the steeply dipping limb, is well separated from the others (Figure 5a) and may result from incomplete separation of magnetic components. However, omission of this specimen from the group alters neither the mean direction nor the fold test result significantly (Figure 5a), hence all 13 directions are used in the final calculation of paleomagnetic poles and their uncertainties.
[13] The second component to be removed (INT), through temperatures of $300^{\circ}-640^{\circ} \mathrm{C}$, is aligned southward and moderately up in present coordinates. Clustering of directions is good at $0 \%$ unfolding, fair to poor at $100 \%$ unfolding, but greatest at $\sim 35 \%$ unfolding (Figure $5 \mathrm{~b}$ ), suggesting a syn-fold remanence. Specimen 6 is once again a marked outlier in present coordinates, perhaps due to overlapping thermal spectra of components as noted above. If this specimen is omitted from the group, the precision of

Table 1. Rock-Magnetic Characteristics of Sampled Sites ${ }^{\mathrm{a}}$

\begin{tabular}{|c|c|c|c|c|c|}
\hline Site & $\begin{array}{c}\mathrm{NRM}^{\mathrm{b}} \\
\mathrm{mA} / \mathrm{m}\end{array}$ & $\begin{array}{c}\chi^{\mathrm{b}}{ }^{\mathrm{b}} 10^{-5} \\
\mathrm{SI}\end{array}$ & $\begin{array}{c}\text { AMS, }^{\mathrm{b}} \\
\%\end{array}$ & $\begin{array}{c}\text { IRM }_{\mathrm{ACQ}}{ }^{\mathrm{c}}{ }^{-} \\
\mathrm{A} / \mathrm{m}\end{array}$ & Components \\
\hline \multicolumn{6}{|c|}{ Red Shales } \\
\hline GFT, GSS & $10-30$ & $30-50$ & $10-20$ & 87 & $\begin{array}{c}\text { LOW, INT, } \\
\text { HIG }\end{array}$ \\
\hline MRM & $5-40$ & 20 & $-{ }^{\mathrm{d}}$ & 15 & INT \\
\hline MSM 10-15 & $5-15$ & 10 & $-{ }^{\mathrm{d}}$ & 18 & INT, INT-2 \\
\hline \multicolumn{6}{|c|}{ Lateritic Iron Ores } \\
\hline MSM $1-7$ & $10-100$ & $100-500$ & $21-23$ & 207 & (scattered) \\
\hline MIB & $20-200$ & $75-200$ & $6-8$ & 283 & $\mathrm{HIG}^{(-)}$ \\
\hline \multicolumn{6}{|c|}{ Hartley Lava } \\
\hline HLO & $10-400$ & $500-10,000$ & $10-250$ & 364 & HLO \\
\hline
\end{tabular}

${ }^{\mathrm{a}}$ Abbreviations: NRM, natural remanent magnetization; $\chi$, bulk susceptibility at room temperature; AMS, anisotropy of magnetic susceptibility; $\mathrm{IRM}_{\mathrm{ACQ}}$, isothermal-remanent magnetization acquisition. For site and component abbreviations, see text.

${ }^{\mathrm{b}}$ Range of typical values encountered at each site.

${ }^{c}$ Magnetization acquired in a pulse field of $100 \mathrm{mT}$. One specimen analyzed per site.

${ }^{\mathrm{d}}$ Additional sample material not available for this experiment. 


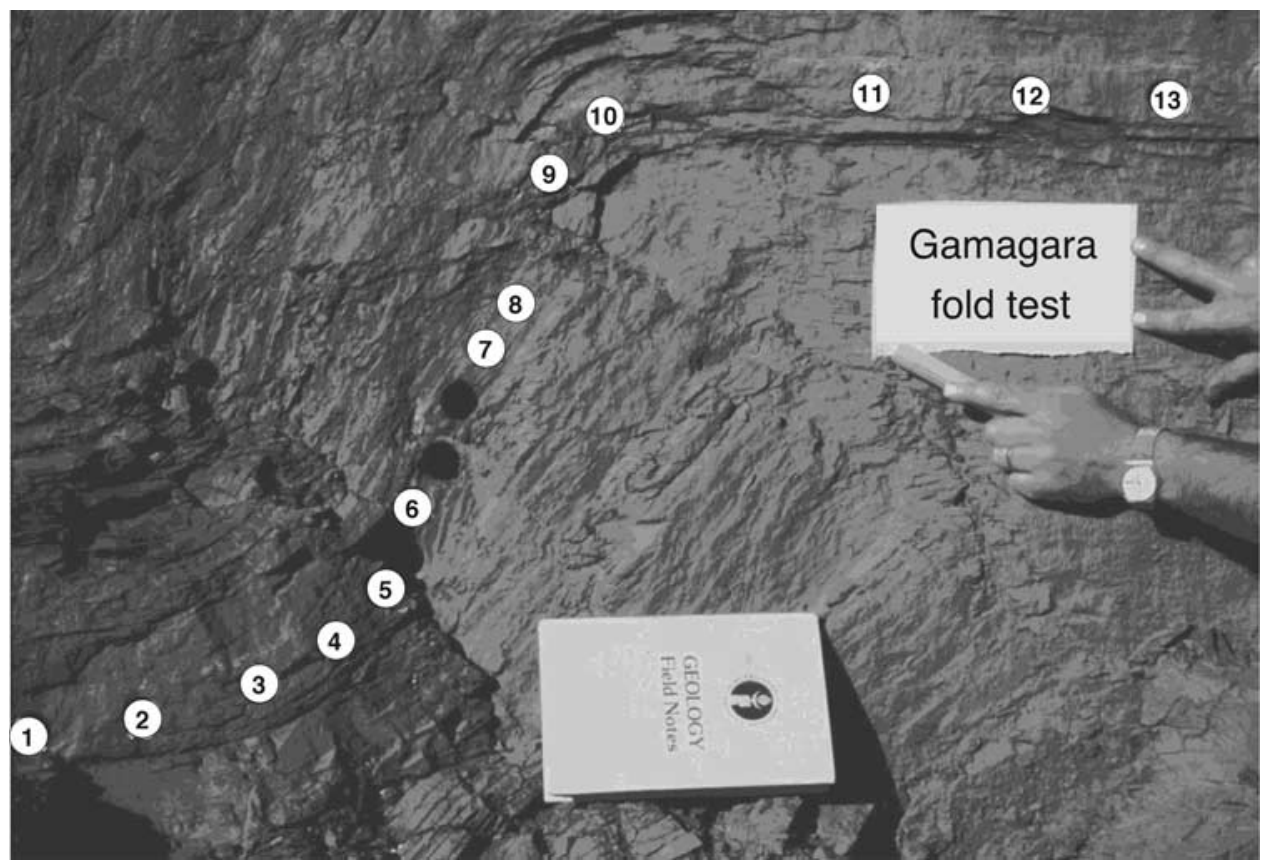

Figure 3. Field photograph, looking east, of the GFT fold test at South Sishen. Holes lacking sample numbers (in shadow) mark crumbled and unusable cores. Text has been enhanced digitally.

the mean is greatly improved yet the highest grouping is still obtained from partial unfolding ( $25 \%$; Figure $5 \mathrm{~b})$. The mean direction does not change significantly and hence all 13 samples will be considered hereafter (Table 2). Unlike the LOW component, the INT component's grouping at $0 \%$ unfolding is significantly less than the peak at $\sim 30 \%$, at the 95\% confidence level [Fisher et al., 1987, p. 219]. The synfold interpretation thus appears to be robust. Furthermore, because INT lies far from the mixing plane containing LOW and HIG (see below), one can rule out an origin as a spurious overlap in unblocking spectra of those other components. The broad unblocking temperature spectrum for the INT component suggests that it is carried by hematite in a range of grain sizes or hydrothermal acquisition temperatures.

[14] The third component (HIG), represented as the endpoint of each sample's demagnetization trajectory (here computed as a least squares line including the $615^{\circ}, 640^{\circ}$, and $660^{\circ} \mathrm{C}$ steps and anchored to the origin), is definitively prefold in origin and directed eastward and moderately down in tilt-corrected coordinates (Figure 5c). Because of the relatively coarse demagnetization undertaken within the hematite unblocking temperature range for the GFT samples, it is possible that the endpoints attained are not truly "stable" and that the true HIG direction lies farther to the north (see below).

[15] These three magnetic components are observed also in each of the 12 samples from the virtually undeformed GSS subsuite in the South Sishen Mine (Figure 6). Greater care was taken at the higher-temperature demagnetization steps among these specimens, demonstrating that true stable endpoints define the HIG component. Accordingly, the mean direction for this component is slightly north of that from the GFT subsuite (Figure 7) and probably provides a more accurate estimate of the true HIG direction.
For the final mean calculation of the South Sishen Mine samples, the HIG lines determined from GSS samples are combined with least squares planes from the GFT samples, containing the INT line and anchored to the origin for each specimen (Figure 7 and Table 2) [McFadden and McElhinny, 1988].

\subsection{Rooinekke Mine (MRM)}

[16] At the Rooinekke Mine in the southern part of the Griqualand West region (Figure 2), 16 samples were collected from red shales of the Mapedi Formation, correlative with the Gamagara Formation farther north. The Rooinekke area is sliced by numerous splays of the Blackridge thrust system [Grobbelaar et al, 1995]. Only one magnetic component is preserved within each specimen, nearly collinear with the synfolding INT direction at Sishen (Figure 8).

\subsection{North Sishen Mine (MSM)}

[17] At a more northerly locality within the Sishen Mine complex, about $4 \mathrm{~km}$ north of the GSS and GFT sites, our sample suite included seven oriented blocks from slightly folded hematitic ore within the sub-Gamagara/Mapedi paleoweathering zone, six cores from subhorizontal red shales of the Gamagara Formation, and one large block from an overlying conglomerate containing small pebble-sized clasts of the hematitic ore. The folding of hematitic ore occurred prior to Gamagara redbed deposition.

[18] Gamagara red shales from the North Sishen Mine (MSM 10-15) have shallow N-S paleomagnetic directions that are not quite antiparallel (Figure 9). The two groups are systematically related to unblocking temperature: the dominating north-directed component is removed between $250^{\circ}$ and $650^{\circ} \mathrm{C}$, and the south-directed component is removed at $650^{\circ}-680^{\circ} \mathrm{C}$. The stable endpoint (southward) direction at this locality corresponds precisely with the INT direction 


\section{GFT 1}

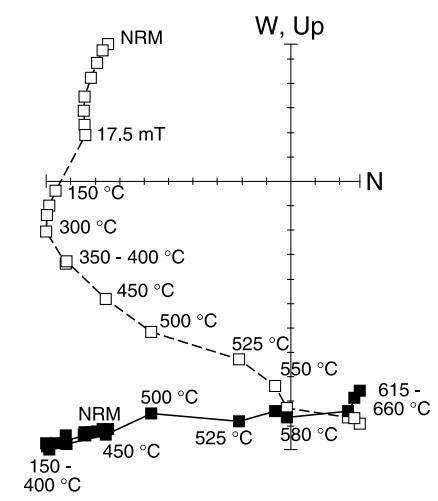

GFT 11
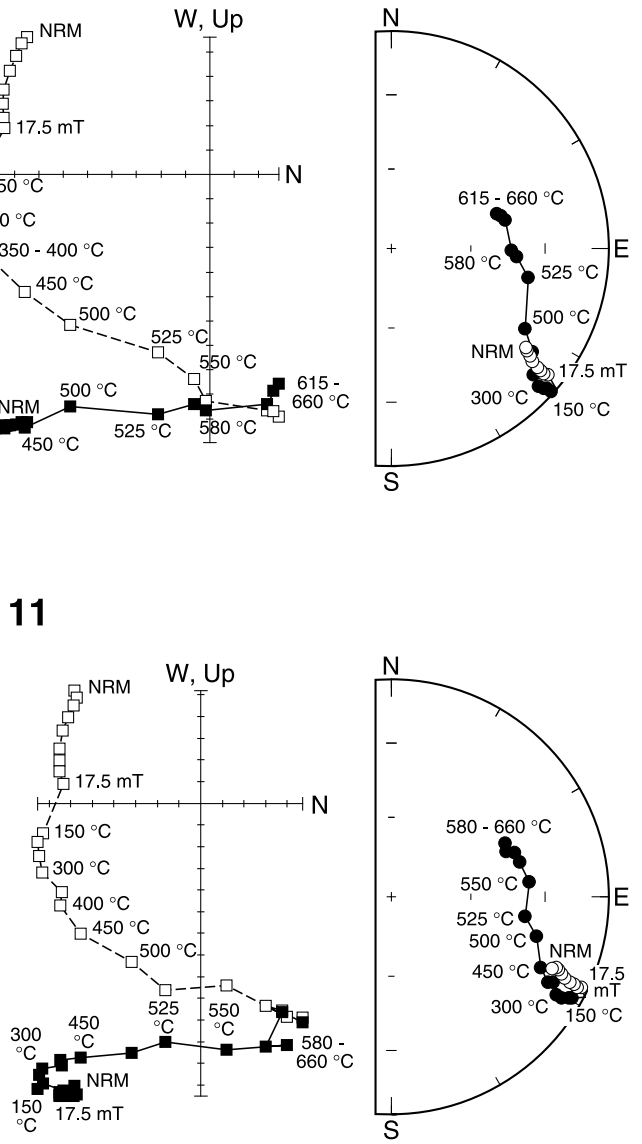
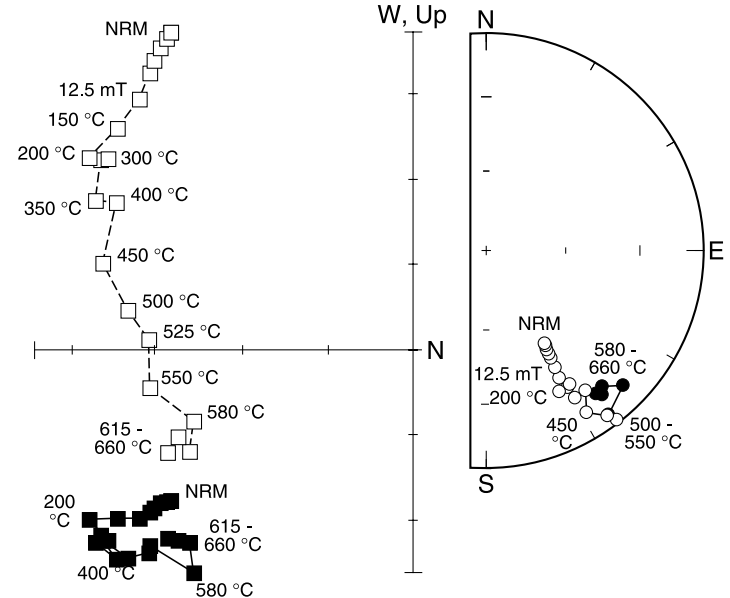

GFT 9

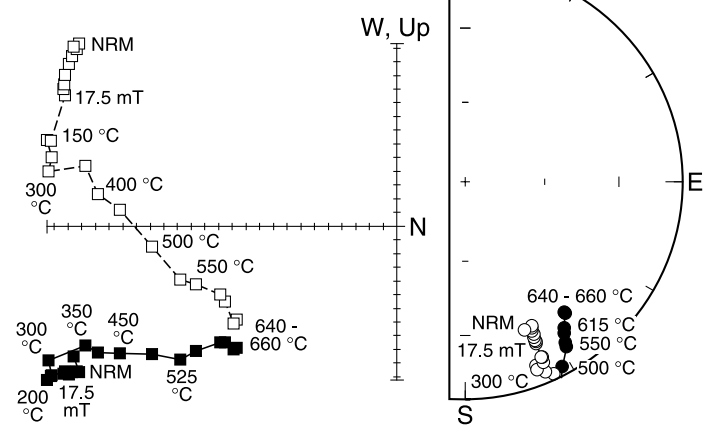

Figure 4. Representative sample behavior, in situ field coordinates, from site GFT, South Sishen Mine. Samples 1, 11 are from subhorizontal strata; samples 6, 9 are from steeply N-dipping strata. Orthogonal projection plots: solid $=$ horizontal plane, open $=\mathrm{N}-\mathrm{S}$ and vertical plane, tick marks $10^{-8} \mathrm{Am}^{2}$. Equalarea plots: solid $=$ lower hemisphere, open $=$ upper hemisphere NRM $=$ natural remanent magnetization .

from sites GFT and GSS, and is interpreted as a coeval remagnetization.

[19] The north-directed component ("INT-2") from North Sishen Gamagara shales, with moderate unblocking temperatures, could be broadly related to this overprinting event; misalignment of the two polarities could result from apparent polar wander or nondipolar geomagnetic field behavior. A final possibility, however, is that the INT-2 direction is contaminated by a steep upward component with a strongly overlapping unblocking temperature spectrum. In fact, two shale specimens show clear removal of such a steep upward component below $400^{\circ}-500^{\circ} \mathrm{C}$, similar to "LOW" from the South Sishen Mine. Because of the possibility of such a bias lurking within the INT-2 direction, we are cautious to consider any of its putative implications, except that it qualitatively demonstrates dual-polarity (and hence, considerable duration) of our regional INT overprint.

[20] Both subsets of hematitic ore samples, the conglomerate clasts and the in situ orebody within the paleoweathering zone, yielded primarily stable-endpoint magnetizations at $\sim 680^{\circ} \mathrm{C}$, and sometimes a lower unblocking-temperature component generally removed between $300^{\circ}$ and $600^{\circ} \mathrm{C}$ (sometimes as high as $675^{\circ} \mathrm{C}$ ). All of these groups of directions are greatly dispersed (Figure 10). We consider this conglomerate test to be inconclusive, because although the clast directions are highly scattered, the underlying source material behaves similarly unstably.

\subsection{Manganore Iron Ore at Beeshoek (MIB)}

[21] The sub-Gamagara/Mapedi paleoweathering zone is well exposed at Beeshoek Mine, where we sampled eight small oriented blocks of hematite-enriched Kuruman ironformation from the walls of the "HL Pit." Bedding in the iron-formation undulates up to $30^{\circ}$ to the east and west; these structures developed via slumping into sinkhole structures, immediately prior to hematitization and Gamagara deposition [Grobbelaar and Beukes, 1986]. The Gamagara red beds are not exposed at this precise locality, but fold axes within the iron-formation are horizontal, suggesting no discernible tilting since the time of the unconformity. Six of the eight specimens showed virtually no removal of magnetization through temperatures as high as $664^{\circ} \mathrm{C}$, and 
a.
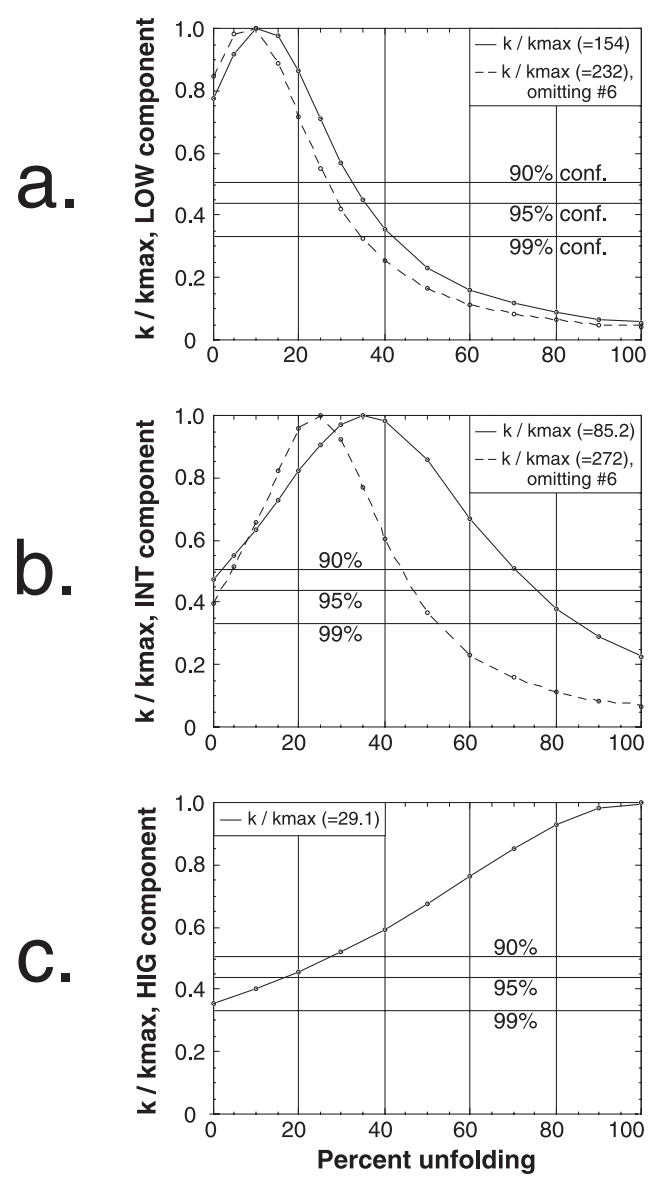

Present

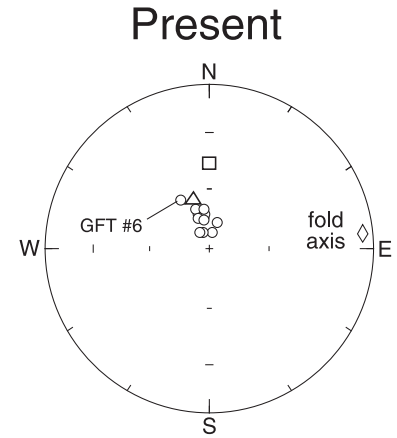

Tilt-corrected
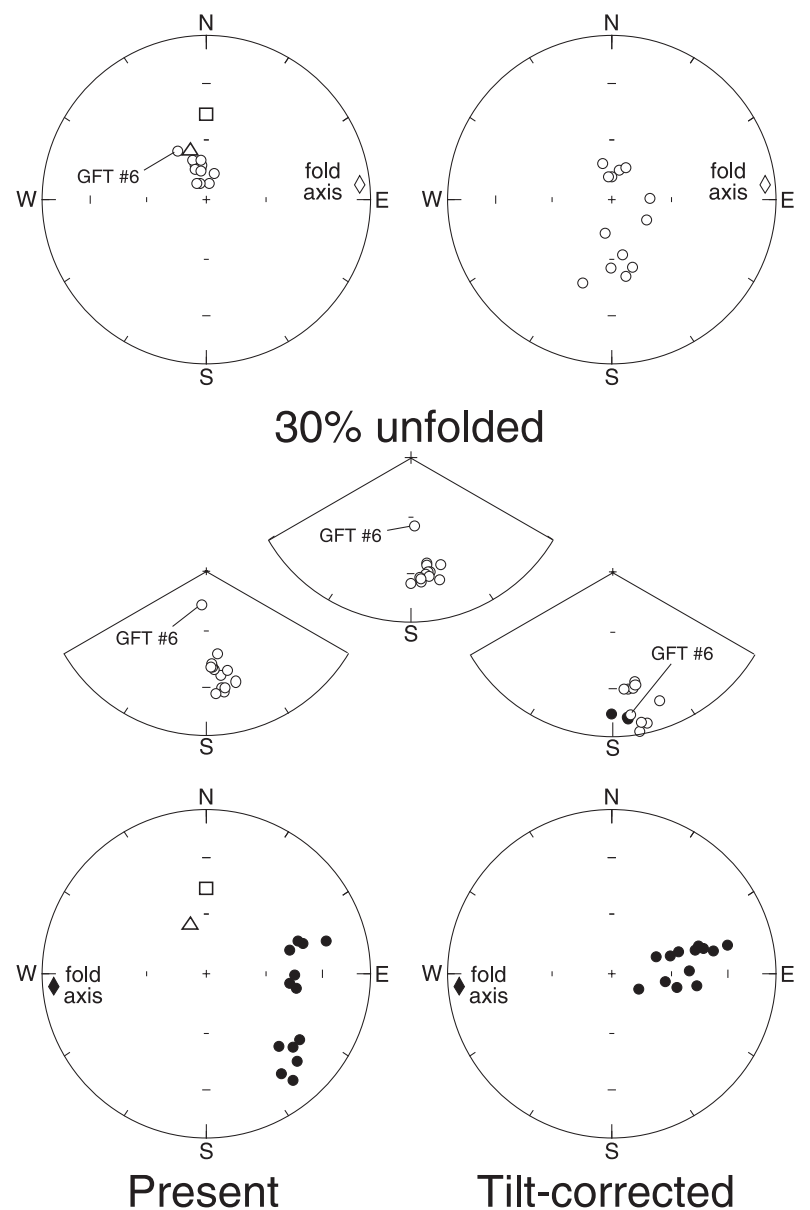

Tilt-corrected

Figure 5. Summary of GFT fold test: (a) LOW component, (b) INT component, (c) HIG component. Left panels: normalized precision parameter $(k)$ [Fisher, 1953] versus degree of unfolding. Solid curves $=$ all samples, dashed curves $=$ omitting outlying specimen 6 , horizontal bars $=$ confidence limits for precision statistically distinct from maximum value [Fisher et al., 1987, p.219; $\mathrm{N}=12$ ]. Right panels: equal-area projections of directional data, with various degrees of unfolding, symbols as in Figure 4. Square $=$ present geocentric axial dipole field direction at the sampling site; triangle $=$ present local field at sampling site.

they acquired spurious directions at the $680^{\circ} \mathrm{C}$ step (Figure 11). These six directions are moderately clustered in a shallow-upward and westerly orientation. The other two specimens show slight removal of a less stable component before reaching a stable endpoint like the others. Of these, one (MIB 5) has both components oriented shallowly southward, which we interpret to be related to the INT overprint observed at other localities (Figure 11).

[22] Omitting the outlying sample MIB 5, the other seven specimens' mean stable-endpoint direction is approximately antipolar to the HIG component observed at South Sishen Mine (sites GFT, GSS). Correction for the pre-Gamagara undulations in bedding produces no significant change to either the precision or the direction of this " $\mathrm{HIG}^{(-)}$" mean (Figure 11 and Table 2).

[23] The age of $\mathrm{HIG}^{(-)}$remanence is constrained by a conglomerate test on hematite-enriched ore pebbles from the Doornfontein Conglomerate Member above the unconformity (similar to that attempted at locality MSM). This locality lies $1.5 \mathrm{~km}$ north of the other MIB sites. Here, results of the conglomerate test are clear; high dispersion among 15 individually sampled clasts with well-behaved magnetic signatures (Figure 11) indicates that the hematitic enrichment occurred prior to the scattering of pebbles and their entrainment in the sediment. Applying a formal test [Fisher et al., 1987, pp. 110, 253], the null hypothesis of uniformity ("randomness") can be rejected with only $\sim 50 \%$ confidence, well below the standard $95 \%$ criterion. It is crucial for a proper test that $\mathrm{HIG}^{(-)}$directions from the in situ orebody, beneath the unconformity, group with much better precision, and indeed in this case uniformity ("randomness") can be rejected with greater than $99 \%$ confidence [Fisher et al., 1987, pp. 110, 262].

[24] Hematite enrichment at Beeshoek thus occurred prior to deposition of the lower Olifantshoek red beds; but did it occur before or after folding of the Kuruman iron-formation substrate? Our fold test on $\mathrm{HIG}^{(-)}$stable endpoint directions is inconclusive (Table 2); however, at Sishen the subhorizontal lower boundary of ferruginization cuts across locally intense substrate deformation, supporting a regional model 
Table 2. Least Squares Component Directions ${ }^{\mathrm{a}}$

\begin{tabular}{|c|c|c|c|c|c|c|c|c|c|c|c|}
\hline \multirow{2}{*}{$\begin{array}{c}\text { Component } \\
\text { (Site) }^{\mathrm{b}}\end{array}$} & \multirow[b]{2}{*}{$n / N$} & \multirow[b]{2}{*}{$\mathrm{L} / \mathrm{P}$} & \multirow[b]{2}{*}{$T_{\text {unbl }},{ }^{\circ} \mathrm{C}$} & \multicolumn{4}{|c|}{ Present coordinates } & \multicolumn{4}{|c|}{ Tilt-corrected coordinates } \\
\hline & & & & $D, \operatorname{deg}$ & $I$, deg & $K$ & $\alpha_{95}, \operatorname{deg}$ & $D, \operatorname{deg}$ & $I, \operatorname{deg}$ & $K$ & $\alpha_{95}, \mathrm{deg}$ \\
\hline \multicolumn{12}{|l|}{ LOW } \\
\hline GFT & $13 / 13$ & $\mathrm{~L}$ & $0-250$ & 345.1 & -74.0 & 153.7 & 3.4 & 165.8 & -78.9 & 10.8 & 13.2 \\
\hline GSS & $12 / 12$ & $\mathrm{~L}$ & $0-250$ & 320.6 & -69.1 & 86.4 & 4.7 & 320.0 & -59.3 & 88.3 & 4.6 \\
\hline Combined & $25 / 25$ & $\mathrm{~L}$ & & $\underline{331.8}$ & -72.1 & 85.0 & $\underline{3.2}$ & & & & \\
\hline \multicolumn{12}{|l|}{ INT } \\
\hline GFT & $13 / 13$ & $\mathrm{~L}$ & & 173.5 & -38.2 & 40.3 & 6.6 & 171.6 & -12.2 & 19.3 & 9.7 \\
\hline $\mathrm{GFT}^{\mathrm{c}}$ & $13 / 13$ & $\mathrm{~L}$ & $300-580$ & 172.5 & -31.1 & 82.6 & 4.6 & & & & \\
\hline GSS & $12 / 12$ & $\mathrm{~L}$ & & 185.6 & -22.8 & 313.0 & 2.5 & 189.4 & -29.3 & 323.0 & 2.4 \\
\hline $\mathrm{GSS}^{\mathrm{c}}$ & $12 / 12$ & $\mathrm{~L}$ & $300-580$ & 186.6 & -24.7 & 313.0 & 2.5 & & & & \\
\hline Combined $^{c}$ & $25 / 25$ & $\mathrm{~L}$ & & 179.5 & -28.2 & 65.7 & 3.6 & & & & \\
\hline MSM & $6 / 6$ & $\mathrm{~L}$ & $650-676+$ & $\overline{174.0}$ & $-\overline{27.5}$ & $\overline{37.4}$ & $1 \overline{1.1}$ & 166.9 & -34.9 & 38.2 & 11.0 \\
\hline MRM & $16 / 16$ & $\mathrm{~L}$ & $150-675$ & $\overline{180.0}$ & -07.8 & $\overline{60.4}$ & $\frac{4.8}{4}$ & $\overline{181.0}$ & $-\overline{11.1}$ & $\overline{48.6}$ & 5.3 \\
\hline \multicolumn{12}{|l|}{ INT-2 (MSM) } \\
\hline Clasts & $4 / 15$ & $\mathrm{~L}$ & $300-580$ & 004.7 & -39.2 & 24.4 & 19.0 & 009.4 & -45.3 & 24.4 & 19.0 \\
\hline Shales & $6 / 6$ & $\mathrm{~L}$ & $200-625$ & 023.1 & -27.2 & 14.0 & 18.6 & 025.3 & -14.6 & 14.1 & 18.5 \\
\hline Combined & $10 / 21$ & $\mathrm{~L}$ & & $\underline{016.2}$ & $-\underline{32.4}$ & 14.7 & $\underline{13.0}$ & 020.0 & -27.2 & 10.4 & 15.7 \\
\hline \multicolumn{12}{|l|}{ HIG } \\
\hline GFT & $13 / 13$ & $\mathrm{~L}$ & $>660$ & 110.3 & 38.4 & 10.4 & 13.5 & 081.3 & 52.4 & 29.1 & 7.8 \\
\hline GSS & $12 / 12$ & $\mathrm{~L}$ & $660-680+$ & 060.5 & 46.3 & 45.2 & 6.5 & 070.1 & 43.3 & 45.0 & 6.5 \\
\hline Combined & $25 / 25$ & $\mathrm{~L} \oplus \mathrm{P}^{\mathrm{d}}$ & & & & & & 067.6 & 48.3 & 19.4 & 7.9 \\
\hline \multicolumn{12}{|l|}{$\mathbf{H I G}^{(-)}$} \\
\hline MIB & $7 / 8$ & $\mathrm{~L}$ & $>664$ & 259.7 & -27.6 & 7.7 & 23.3 & 261.4 & -26.2 & 9.5 & 20.7 \\
\hline HIG + HIG $^{(-)}$ & $32 / 33$ & $\mathrm{~L} \oplus \mathrm{P}^{\mathrm{d}}$ & & & & & & 072.1 & 44.2 & 10.7 & 9.2 \\
\hline \multicolumn{12}{|l|}{ HLO } \\
\hline 1 & $4 / 4$ & $\mathrm{~L}$ & & 311.7 & 25.2 & 89.8 & 9.7 & 309.8 & 25.8 & 89.8 & 9.7 \\
\hline 2 & $3 / 4$ & $\mathrm{~L}$ & & 284.9 & 37.5 & 32.8 & 21.9 & 282.1 & 36.2 & 32.8 & 21.9 \\
\hline 3 & $4 / 4$ & $\mathrm{~L}$ & & 323.9 & 70.5 & 10.9 & 29.1 & 312.7 & 71.6 & 10.9 & 29.1 \\
\hline 5 & $2 / 4$ & $\mathrm{~L}$ & & 297.4 & 38.3 & 20.5 & 58.3 & 294.3 & 37.9 & 20.5 & 58.3 \\
\hline 6 & $4 / 4$ & $\mathrm{~L}$ & & 319.2 & 42.6 & 14.9 & 24.6 & 315.6 & 43.7 & 14.9 & 24.6 \\
\hline 7 & $3 / 4$ & $\mathrm{~L}$ & & 310.7 & 40.6 & 8.8 & 44.2 & 307.3 & 41.0 & 8.8 & 44.2 \\
\hline Combined $^{\mathrm{e}}$ & $20 / 31$ & $\mathrm{~L}$ & $<580$ & 308.1 & 43.4 & $\begin{array}{r}0.0 \\
11.1 \\
\end{array}$ & 10.3 & 304.3 & 43.6 & $\begin{array}{r}0.0 \\
11.1 \\
\end{array}$ & 10.3 \\
\hline
\end{tabular}

${ }^{a}$ Abbreviations: $n / N$, number of specimens included in mean/number analyzed; L/P, line versus plane least squares analysis $\left[\right.$ Kirschvink, 1980]; $T_{\text {unbl }}$, unblocking temperature spectrum; $D$, mean declination; $I$, mean inclination; $K$, Fisher's [1953] precision parameter, except in modified form where lines and planes are combined [McFadden and McElhinny, 1988]; $\alpha_{95}$, radius of $95 \%$ confidence cone about mean. Underlined, used to calculate paleomagnetic poles (Tables 2 and 3).

${ }^{\mathrm{b}}$ Site locations: GFT, GSS, and MSM $\left(27.8^{\circ} \mathrm{S}, 023.0^{\circ} \mathrm{E}\right)$; MRM $\left(28.9^{\circ} \mathrm{S}, 022.7^{\circ} \mathrm{E}\right)$; MIB $\left(28.3^{\circ} \mathrm{S}, 023.0^{\circ} \mathrm{E}\right) ; \operatorname{HLO}\left(27.9^{\circ} \mathrm{S}, 022.8^{\circ} \mathrm{E}\right)$.

${ }^{\mathrm{c}}$ Mean INT directions from sites GFT and GSS at 30\% partial unfolding.

${ }^{\mathrm{d} C}$ Combined analysis [McFadden and McElhinny, 1988] of unit-weighted least squares lines (GSS and MIB) and planes (GFT); MIB sample directions are considered in present coordinates whereas GFT and GSS are tilt corrected (see text).

${ }^{\mathrm{e}}$ Unit weight to samples; 7 of 31 total samples are from excluded sites 4 and 8 .
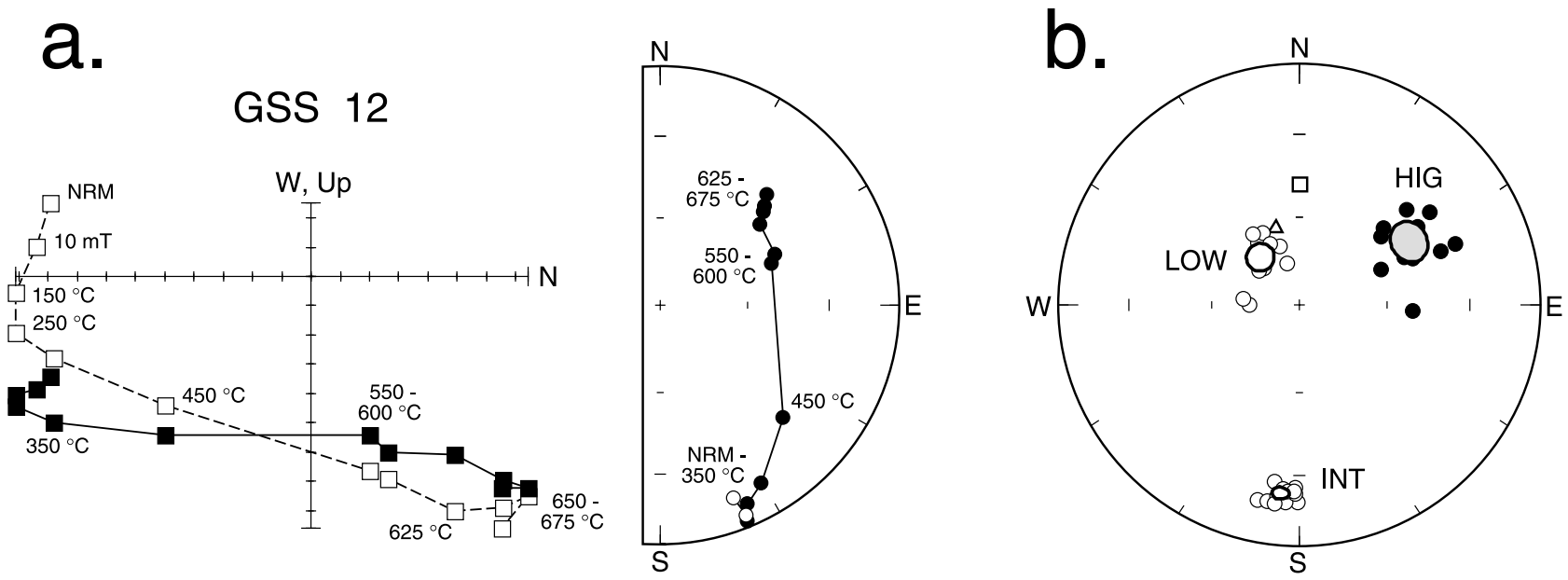

Figure 6. Data from site GSS, in situ coordinates, South Sishen Mine; symbols as in Figures 3 and 4. (a) Representative GSS sample behavior. (b) Equal-area projection of least squares linear components. Dark ovals $=$ projections of Fisher distribution $95 \%$ confidence cones about the component mean directions. 


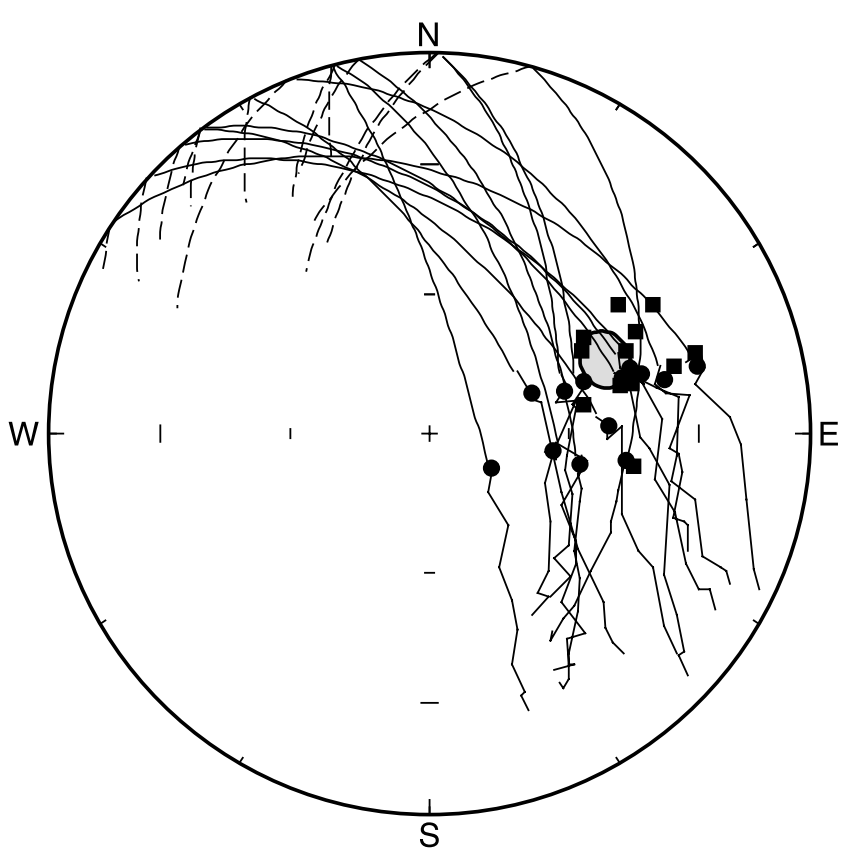

Figure 7. Combination of GSS lines and GFT planes to produce the Fisher mean of component HIG at South Sishen; equal-area projection, $100 \%$ tilt-corrected coordinates. Squares $=$ least squares lines from GSS, circles $=$ least squares lines from GFT (not used in mean calculation; see text), unsmooth curves in SE quadrant $=$ demagnetization chords from each of the GFT specimens, smooth curves in $\mathrm{NE}$ and NW quadrants = loci of possible HIG components from planar extrapolation of the GFT data (upper hemisphere dashed), dark oval $=$ Fisher mean of 12 GSS lines and 13 GFT planes, following McFadden and McElhinny [1988].

of hematite-enrichment shortly prior to Gamagara/Mapedi deposition [Van Schalkwyk and Beukes, 1986]. We therefore consider the $\mathrm{HIG}^{(-)}$and HIG components to represent virtually the same remanence age: the end of the paleoweathering interval and the onset of redbed deposition. The $\mathrm{HIG}^{(-)}$remanence from Beeshoek, considered in postunconformity (horizontal) coordinates, is approximately antipolar to the fold-corrected HIG direction from South Sishen (Table 2); however, the quantitative reversals test $[\mathrm{McF}$ adden and McElhinny, 1990] is indeterminate for these groups.

\subsection{Hartley Lava at Olifantshoek (HLO)}

[25] Eight subhorizontal flow-units are exposed continuously over $500 \mathrm{~m}^{2}$ in the walls of a quarry for road aggregate at Hartley Hill near Olifantshoek. This unique exposure is the least altered locality of the lavas; here they are virtually undeformed and contain igneous plagioclase, pyroxene, and hornblende, in contrast to the foliated and greenschist-metamorphosed exposures elsewhere [Cornell, 1987]. Flow-units are massive or amygdaloidal, averaging 2 $\mathrm{m}$ in thickness and commonly separated by lenticular tuffaceous siltstone members (all part of unit "HH3" by Cornell [1987]). We sampled four cores from each flow-unit (except sample 8 with only three). One specimen from each flowunit was given the standard demagnetization sequence to $580^{\circ} \mathrm{C}$, whereas the other three were treated with low $\mathrm{AF}$, thermal steps of $150^{\circ}$ and $250^{\circ} \mathrm{C}$, and higher AF to $80 \mathrm{mT}$. In two instances further thermal demagnetization at $610^{\circ}$, $625^{\circ}$, and $640^{\circ} \mathrm{C}$ was necessary to remove residual magnetic components.

[26] Demagnetization trajectories for individual specimens are not as straightforward to interpret as those from the redbed and laterite sites, but when considered as a group a clearer picture emerges. All but one specimen contained a characteristic remanent magnetization (ChRM) with coercivity of about $20-60 \mathrm{mT}$ and unblocking temperature of about $450^{\circ}-580^{\circ} \mathrm{C}$ (Figure 12a). These show moderate scatter (Figure 12b), but most outliers are from samples within flow-units 4 and 8 , which are therefore considered unreliable sites for the modal Hartley magnetization (site 8 does consistently record a direction similar to the INT synfolding overprint described above). The three remaining outlying specimens are omitted simply because of their great angular distance from the mode.

\subsection{Rock-Magnetic Results}

[27] In addition to the numerous field stability tests described above, our directional data can be understood better through rock-magnetic experiments (Table 1). First, the Hartley lavas show near-saturation of IRM acquisition at $100 \mathrm{mT}$ (Figure 13), supporting their $<580^{\circ} \mathrm{C}$ unblockingtemperature spectrum that is characteristic of magnetite. In contrast, all of the redbed and iron-ore samples show very similar IRM acquisition curves (Figure 13), indicating the universal presence of hematite and negligible magnetite. For all red beds and iron ores, the modal field level of IRM acquisition is $\sim 500 \mathrm{mT}$, consistent with a predominance of hematite in the single-domain size range of $1 \mu \mathrm{m}$ or less [Kletetschka et al., 2000].

[28] All sites from the Gamagara/Mapedi red shales contain the INT component; however, only two of these (GFT and GSS) also contain the prefolding HIG component. These sites are characterized by higher bulk susceptibility and greater acquired IRM magnetization at $100 \mathrm{mT}$, than the other redbed sites (Table 1). Dekkers and Linssen [1989] found decreasing levels of saturation remanence in natural hematite as grain size decreased toward the superparamag-
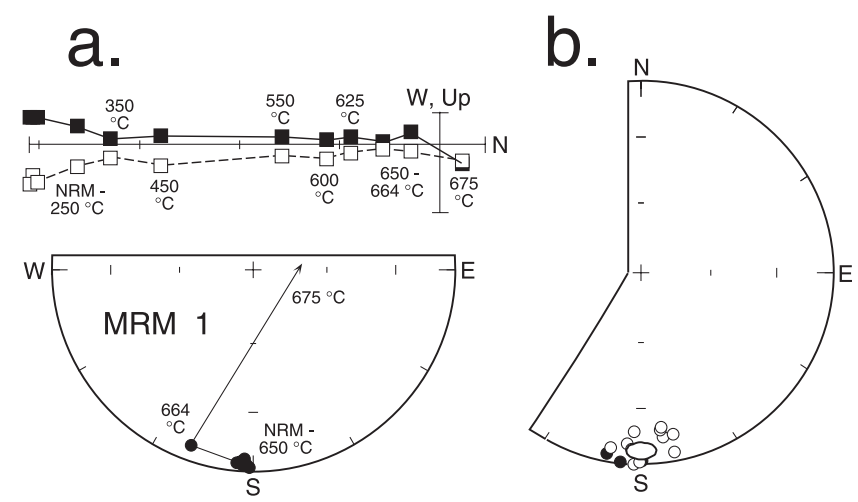

Figure 8. Data from site MRM, Rooinekke Mine, in situ coordinates; symbols as in Figure 6. (a) Representative sample demagnetization behavior; orthogonal projection tick marks $10^{-7} \mathrm{Am}^{2}$. (b) Equal-area projection of least squares linear components and Fisher mean. 

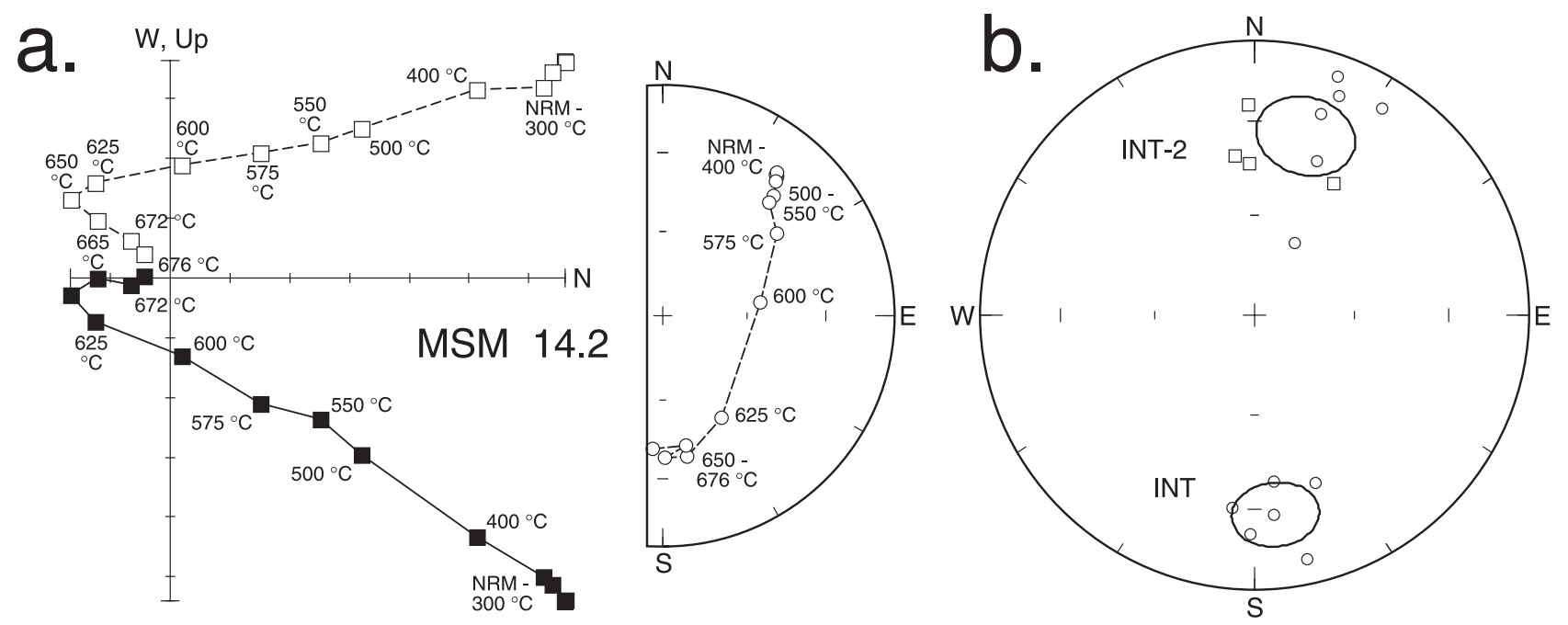

Figure 9. Data from North Sishen Mine samples MSM 10-15 (Gamagara shale), in situ coordinates; for sample locations see Figure 10. (a) Representative sample demagnetization behavior; orthogonal projection tick marks $10^{-8} \mathrm{Am}^{2}$. (b) Equal-area projection of least squares linear components and Fisher means. Symbols as in Figure 6, but also: squares = INT-2 directions from the in situ orebody (see Figure 10).
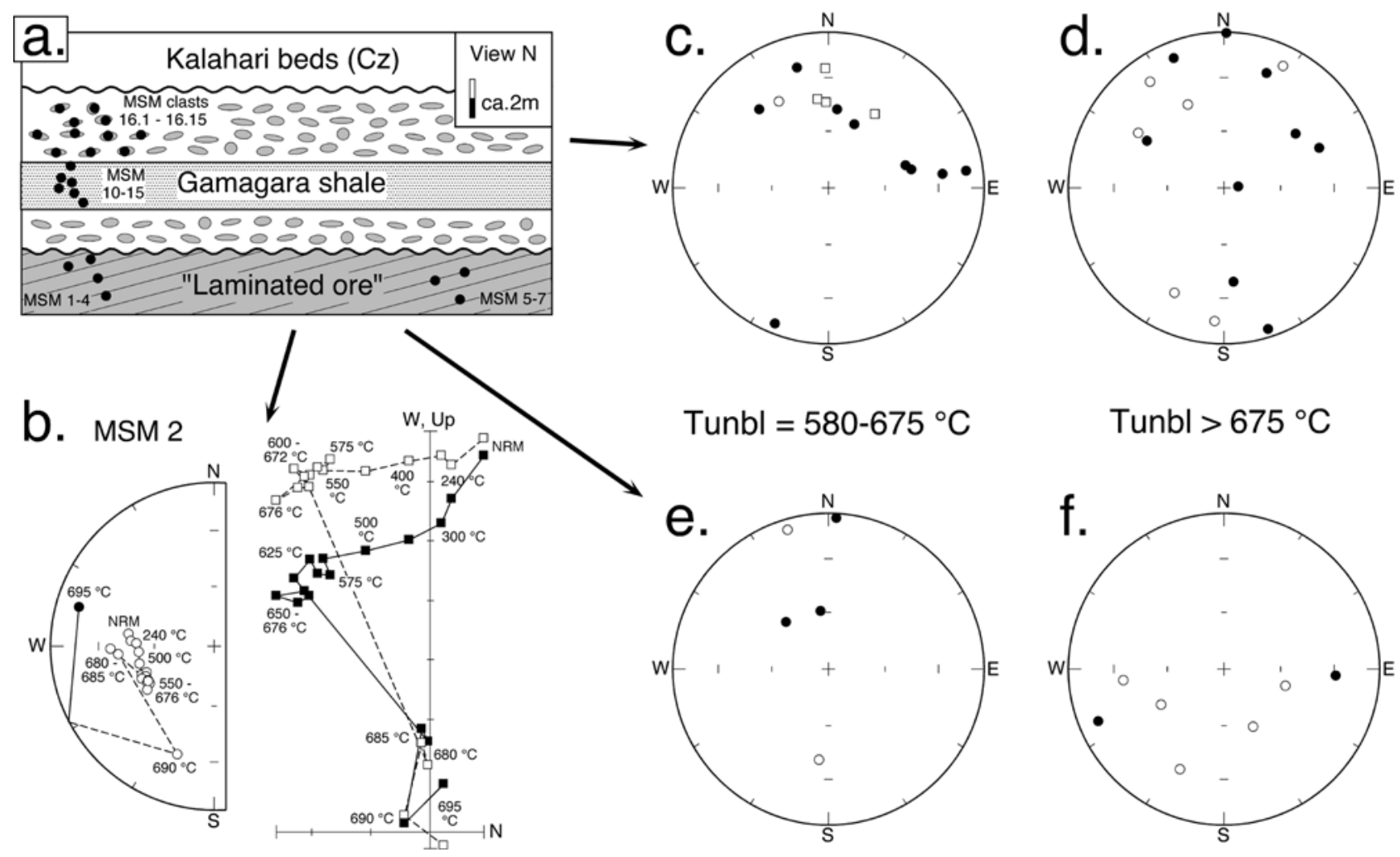

Figure 10. Data from North Sishen Mine, samples MSM 1-7 and conglomerate test, in situ coordinates. (a) Schematic outcrop profile with sample locations. (b) Representative demagnetization behavior, symbols as in Figure 4; orthogonal projection tick marks $10^{-7} \mathrm{Am}^{2}$. (c-d) Intermediate and high unblocking-temperature components from iron-ore clasts in conglomerate. Squares $=$ INT-2 directions included with mean from North Sishen shales (see Figure 9 and Table 2). (e-f) Intermediate and high unblocking-temperature components from in situ iron-ore of the sub-Gamagara/Mapedi paleoweathering zone. Note large scatter among directions in both the conglomerate and paleoweathered subsuites, invalidating the conglomerate test. 

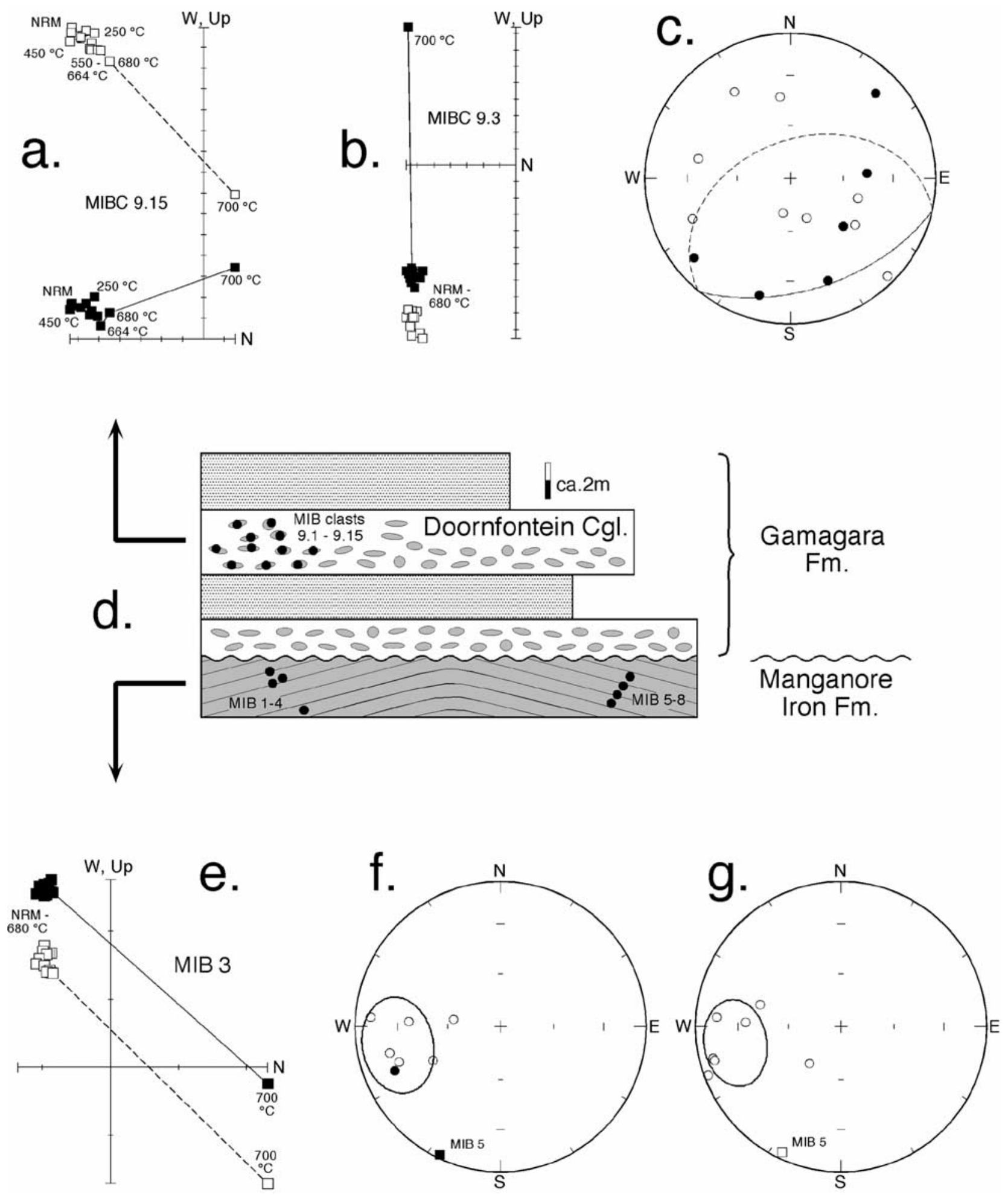

Figure 11. Data from locality MIB, Beeshoek Mine orebody from paleoweathering zone and conglomerate test; symbols as in Figure 6. (a) Conglomerate clast specimen containing a minor overprint component that is removed completely by $680^{\circ} \mathrm{C}$ (the $700^{\circ} \mathrm{C}$ step is spurious); orthogonal projection tick marks $10^{-8} \mathrm{Am}^{2}$. (b) Conglomerate clast with single stable-endpoint component $\left(700^{\circ} \mathrm{C}\right.$ step spurious); tick marks $10^{-7} \mathrm{Am}^{2}$. (c) Equal-area projection of conglomerate clast stable-endpoint directions showing uniform ("random") distribution. Best fit Fisher distribution 95\% error circle (geologically meaningless) extends into both hemispheres. (d) Schematic representation of sampled stratigraphic units. (e) Representative sample demagnetization behavior, in situ coordinates; orthogonal projection tick marks $10^{-6} \mathrm{Am}^{2}$. (f) Equal-area projection of least squares linear components and Fisher mean (omitting sample 5), in situ coordinates. (g) Least squares lines and Fisher mean, corrected for the pre-Gamagara folding. 


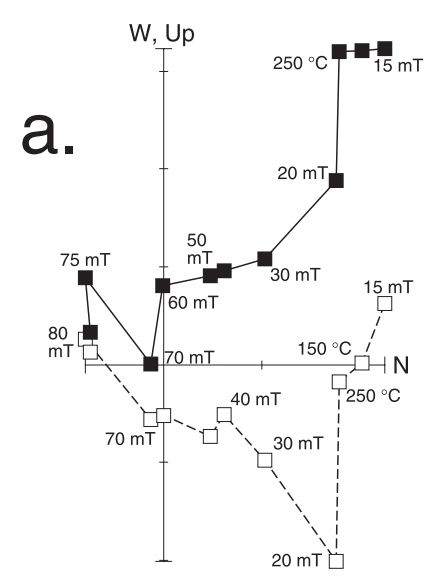

HLO $1 \mathrm{~A}$

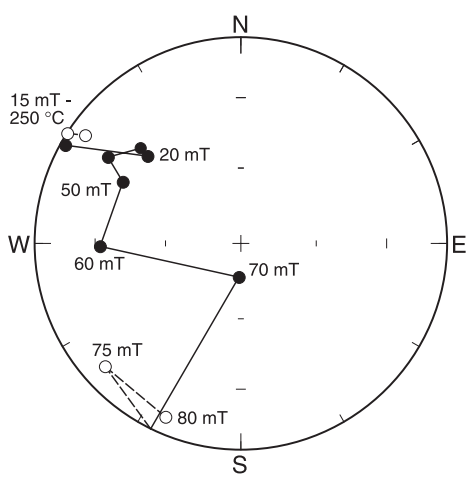

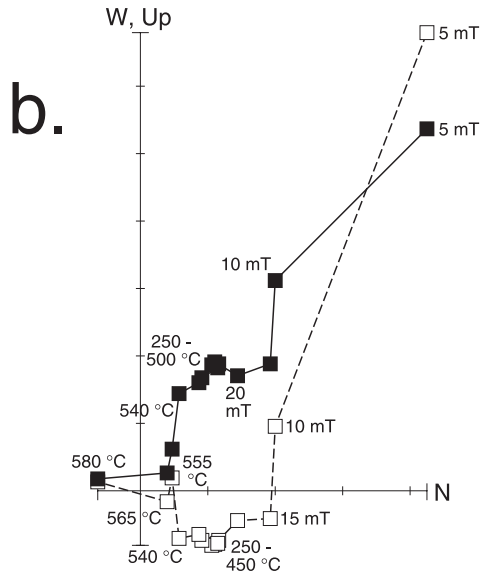

HLO 1D

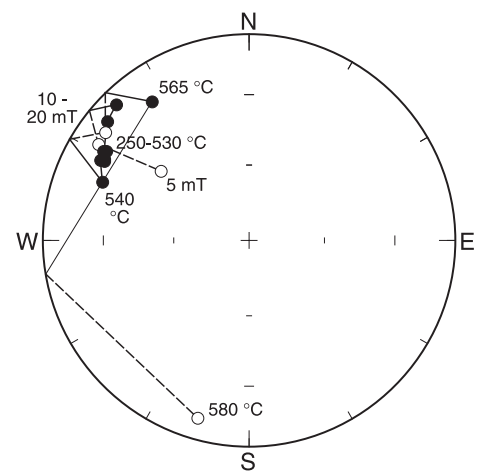

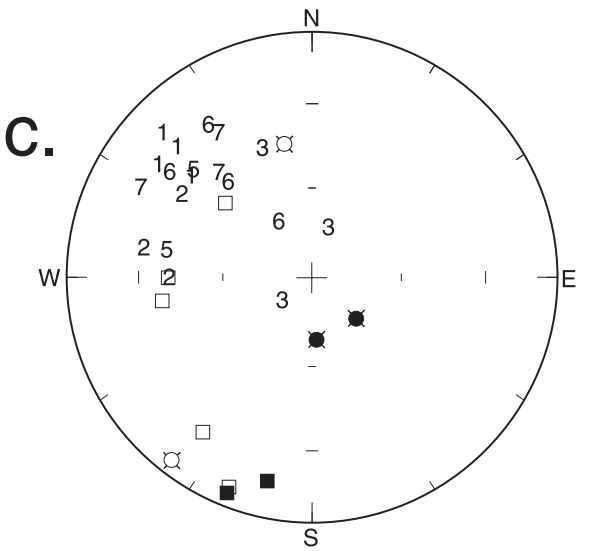

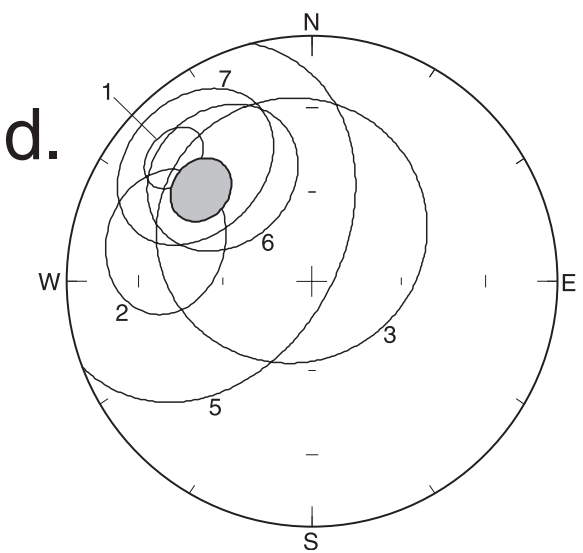

Figure 12. Data from site HLO, the Hartley lava at Olifantshoek, in situ coordinates. (a-b) Representative sample AF (a) and thermal (b) demagnetization behavior, symbols as in Figure 4; orthogonal projection tick marks $10^{-7} \mathrm{Am}^{2}$. (c) Equal-area projection of all least squares linear ChRM directions: squares $=$ specimens from outlying flow-units 4 and 8 , crossed circles $=$ outlying directions from other flow-units, other ChRMs (all lower hemisphere) numbered according to flow-unit. (d) Equalarea lower hemisphere projection of Fisher 95\% confidence cones about flow-unit means (numbered), and Fisher mean of all accepted specimen-weighted ChRM directions (shaded).

netic threshold. Relatively low IRM acquisition levels among the overprinted sites MRM and MSM could indicate an ultrafine grain size spectrum for the hematite in these red beds, in contrast to a slightly broader (still mainly submicron) size spectrum at sites GFT and GSS.

[29] Bulk susceptibility within lateritic iron ore at North Sishen (site MSM) is higher than at Beeshoek (MIB), indicating a primary difference in hematite mineralogy between these localities [cf. Van Schalkwyk and Beukes, 1986; Grobbelaar and Beukes, 1986]. Most importantly, iron ore samples from site MSM, which contain greatly scattered component directions, were found to be consistently more anisotropic than the well behaved ore samples from site MIB (Table 1 and Figure 14). Therefore, the large directional scatter among in situ iron-ore samples MSM 17 , which invalidated the conglomerate test at that site, may be at least partly attributed to these anisotropic effects. A similar behavior in Paleoproterozoic iron-formations from Australia was observed by Schmidt and Clark [1994]. Macroscopically, MSM ore shows fine bedding laminations, whereas our samples of Beeshoek ore are massive. Con-

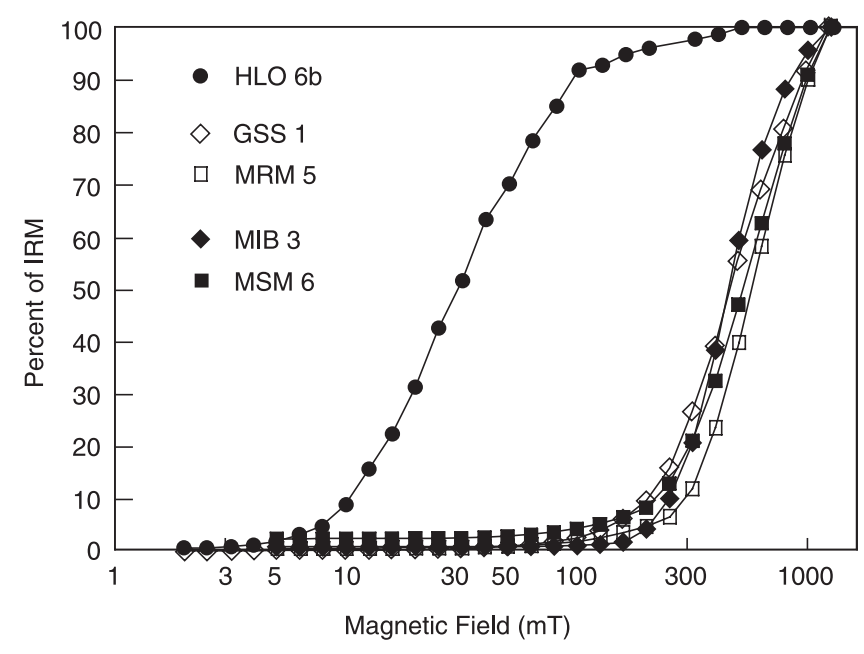

Figure 13. Acquisition of isothermal-remanent magnetization (IRM) among the sampled units. 


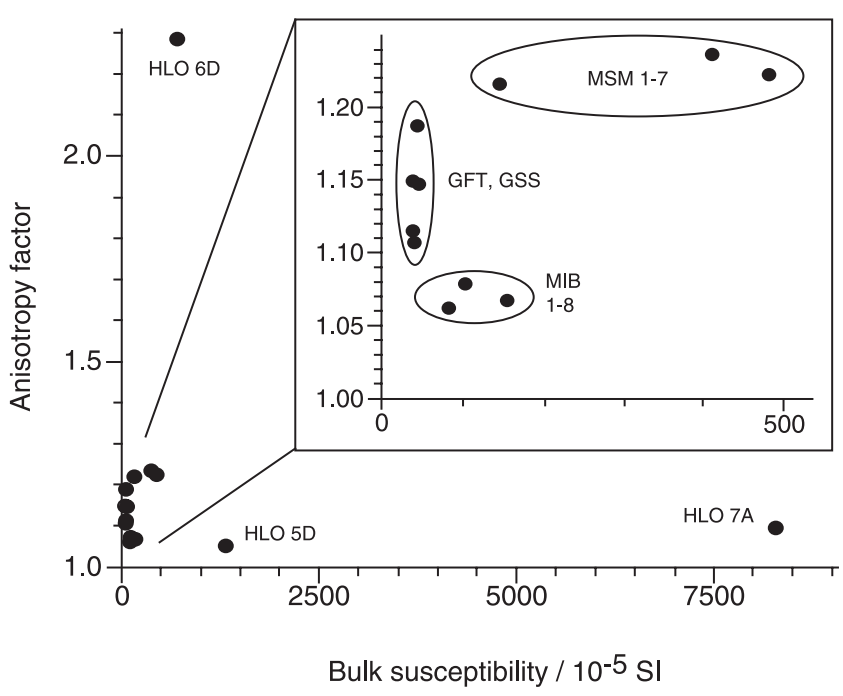

Figure 14. Anisotropy of magnetic susceptibility among the sampled units. All values have been normalized to a standard sample volume of $11 \mathrm{~cm}^{3}$.

glomerate clasts from each area are derived from and share magnetic properties with the immediate substrate.

\subsection{Petrographic Observations}

[30] The various groups of paleomagnetic remanence directions from our data set confirm the multiple generations of hematite observed by us and in previous petrographic studies of the Griqualand West iron orebodies and red beds [Van Schalkwyk and Beukes, 1986; Grobbelaar and Beukes, 1986]. The massive iron ores within the paleoweathering zone are composed of microplaty hematite (a few $\mu \mathrm{m}$ diameter) with a slightly coarser hematitic phase filling small vugs and pore spaces [cf. Van Schalkwyk and Beukes, 1986]. Some of the hematite has replaced magnetite (i.e., martite), whereas locally, other particles are seen to be detrital in origin. The red shales we sampled comprise pyrophyllite and minor amounts of very fine sericite, intergrown with very fine $(\sim 1$ $\mu \mathrm{m}$ diameter or smaller) dusty hematite inclusions. Differing abundances of these hematite grains among shales (greater) and silts (lesser) within the Gamagara/Mapedi Formation suggest a significant detrital origin. However, an early diagenetic population probably also contributes to this group of inclusions. Locally, we observe recrystallization of the dusty hematite pigment into clusters of microplaty hematite or specularite; we interpret this phase as a low-temperature hydrothermal product, especially prevalent at Rooinekke (MRM).

\section{Discussion}

\subsection{Interpretation of Remanence Acquisition}

[31] The LOW component, modest in magnitude but ubiquitously prominent at South Sishen, is removed by $15-20 \mathrm{mT}$ and $250^{\circ} \mathrm{C}$; and is thus probably held by the coarsest-grained hematite as a partial-thermoviscous remanence (pTVRM) and goethite as a crystallization-remanent magnetization (CRM). The INT component is of moderate magnitude at Sishen but predominant at Rooinekke. Its synfolding age and shallow southerly direction both strongly support a Mesoproterozoic age, related to Namaqua orogenesis. Indeed, a prominent splay of the Blackridge thrust is exposed not more than $20-30 \mathrm{~m}$ above our sample sites at Rooinekke. This area has been substantially disrupted by late-Namaqua faults [Grobbelaar et al., 1995], and a hydrothermal origin has been demonstrated for manganese ore in the area [Van Wyk, 1980]. We interpret the INT component as a low- to moderate-temperature, hydrothermal CRM or pTVRM resulting from Namaqua orogenesis, akin to synorogenic hematitization within red beds in the Appalachian foreland [e.g., Lu et al., 1994]. Rock magnetic properties from INT-bearing sites indicate an ultrafine grain-size distribution, and thus the distributed unblocking temperature spectrum $\left(150^{\circ}-675^{\circ} \mathrm{C}\right)$ for INT reflects a broad range of hydrothermal temperatures encountered by these sites.

[32] The HIG/HIG ${ }^{(-)}$component, only observed in South Sishen red beds and with opposite polarity in Beeshoek laminated ore, is always stable beyond $675^{\circ} \mathrm{C}$ and therefore must be carried by nearly pure, uniformly fine-grained, single-domain hematite. According to our rock-magnetic and petrographic observations, the ultrafine, dusty hematite is the most likely carrier of the $\mathrm{HIG} / \mathrm{HIG}^{(-)}$magnetic remanence. South Sishen, the only redbed locality bearing the HIG component, provides a rare window through the otherwise complete Mesoproterozoic hydrothermal overprinting of shales in the immediate vicinity of the Blackridge thrust.

\subsection{Calculation of Mean Paleomagnetic Directions}

[33] Several previous paleomagnetic studies from southern Africa have documented a steep direction that may correspond to the present-day field rather than the timeaveraged geocentric axial dipole [e.g., Morgan, 1985; Evans et al., 1997]. The LOW component from our GFT and GSS samples is significantly steeper than the present-field direction and may be held primarily by supergene goethite that originated from Cretaceous-Paleogene weathering under the so-called African erosional surface [Partridge and Maud, 1987]. Alternatively, the LOW component may have been acquired in Mesozoic time, as suggested by its similarity of its paleomagnetic pole $\left(54.6^{\circ} \mathrm{N}, 229.2^{\circ} \mathrm{E}, \mathrm{dp}=5.0^{\circ}, \mathrm{dm}=\right.$ $\left.5.6^{\circ}\right)$ with the Triassic-Jurassic apparent polar wander (APW) path for Africa [McElhinny and McFadden, 2000, pp. 270-271]. Indeed, the studied region lies near the northern outcrop limit of widespread Early Jurassic dolerite intrusion.

[34] The shallow, N-S components (INT and INT-2) observed at Sishen and Rooinekke show good within-site grouping, but the means from separate localities are significantly distinct (Table 3). Our only temporal constraint on this component comes from South Sishen Mine, where the GFT fold test ascribes a syndeformational (30\% unfolding) remanence acquisition. Because of the general similarities in directions, we interpret all of the shallow, N-S directions to have been acquired during the same broad interval of time, say, 50-100 Myr. Previous paleomagnetic results from the 1100-Ma Umkondo Igneous Province (reviewed by $\mathrm{McEl}$ hinny et al. [1968]; supplemented by Hargraves et al. [1994]) and $\sim 1000-1250 \mathrm{Ma}$ Namaqua Belt [Briden et al., 1979; Onstott et al., 1986a] define an APW loop that encompasses our INT and INT-2 poles (Figure 15). We note that Griqualand West has suffered post-Olifantshoek defor- 
Table 3. Late Mesoproterozoic Overprint Poles From This and Previous Studies ${ }^{\mathrm{a}}$

\begin{tabular}{|c|c|c|c|c|c|c|c|}
\hline $\begin{array}{l}\text { Locality } \\
\text { (Code) }\end{array}$ & & $N$ & $\begin{array}{c}\% \\
\text { Unfold. }\end{array}$ & $\begin{array}{c}\text { Latitude, } \\
{ }^{\circ} \mathrm{N}\end{array}$ & $\begin{array}{c}\text { Longitude, } \\
{ }^{\circ} \mathrm{E}\end{array}$ & $\begin{array}{l}\text { dp, } \\
\text { deg }\end{array}$ & $\begin{array}{l}\text { dm, } \\
\text { deg }\end{array}$ \\
\hline \multicolumn{8}{|c|}{ This Study } \\
\hline $\mathrm{GSS}+\mathrm{GFT}$ & $*$ & 25 & 30 & 47.2 & 022.3 & 2.2 & 3.9 \\
\hline \multirow[t]{2}{*}{ MSM (INT) } & $*$ & 6 & 0 & 47.2 & 014.4 & 6.6 & 12.1 \\
\hline & & & 100 & 41.3 & 006.5 & 7.3 & 12.7 \\
\hline MSM (INT-2) & & 10 & 0 & 71.9 & 082.1 & 8.3 & 14.7 \\
\hline \multirow[t]{2}{*}{ MRM } & * & 16 & 0 & 57.2 & 022.7 & 2.4 & 4.8 \\
\hline & & & 100 & 55.5 & 024.5 & 2.7 & 5.4 \\
\hline Mean (INT only) & & 3 & & 50.6 & 019.6 & 9.9 & 9.9 \\
\hline \multicolumn{8}{|c|}{ From Onstott et al. [1986a] } \\
\hline $82-20$ & $*$ & 5 & 0 & 36.7 & 011.6 & 11.3 & 18.6 \\
\hline $82-21$ & $*$ & 6 & 0 & 38.4 & 059.6 & 10.9 & 20.2 \\
\hline $82-22$ & $*$ & 4 & 0 & 46.1 & 353.7 & 8.9 & 17.2 \\
\hline $82-23$ & $*$ & 3 & 0 & 31.0 & 024.0 & 8.1 & 12.6 \\
\hline \multicolumn{8}{|c|}{ Combined } \\
\hline $\begin{array}{l}\text { Namaqua Eastern } \\
\text { Zone (NEZ) }\end{array}$ & & 7 & & 44.9 & 021.5 & 12.8 & 12.8 \\
\hline
\end{tabular}

a Abbreviations: $N$, number of specimens (localities for grand means); $\%$ unfold., proportion of applied tilt correction; dp, dm, semiaxes of $95 \%$ confidence cone about mean; *, used in calculation of mean pole NEZ (unit weight). Site abbreviations as in Tables 1 and 2 .

mation only in two episodes: the Kheis and Namaqua orogenies [Stowe, 1983; Altermann and Hälbich, 1991]. Because our syn-folding INT component is so similar to previous late Mesoproterozoic directions from the Kalahari craton, we believe there is a strong suggestion that it was acquired during (early) Namaqua orogenesis. If such a comparison is appropriate, then at least some of the deformation in the foreland of the so-called Kheis Province is actually of Namaqua age [cf. Moen, 1999]. The differences among our four INT-related poles may be due to APW of the Kalahari craton or incomplete isolation of magnetic components. We believe this latter effect to be insignificant at the GSS, GFT, and MRM sites, but possibly significant within the INT-2 direction at North Sishen Mine (MSM).

[35] We may combine the virtual geomagnetic poles (VGPs) from our three INT-bearing localities (South Sishen, North Sishen, and Rooinekke) - omitting the INT-2 mean because of its outlying direction and possibility for component contamination-to obtain a paleomagnetic pole at $\left(50.6^{\circ} \mathrm{N}, 019.6^{\circ} \mathrm{E}, K=155, A_{95}=9.9^{\circ}\right)$. This result is indistinguishable from the previous Gordonia Subprovince pole of the eastern Namaqua belt [Onstott et al., 1986a]. We have therefore combined our three localities with the four studied by Onstott et al., to generate a grand mean pole at $\left(44.9^{\circ} \mathrm{N}, 021.5^{\circ} \mathrm{E}, K=23.2, A_{95}=12.8^{\circ}\right)$. Onstott et al. [1986a] performed ${ }^{40} \mathrm{Ar} /{ }^{39} \mathrm{Ar}$ analyses on cummingtonite from the Jannelsepan Formation (their site 82-20) of the Namaqua belt's Eastern Zone (NEZ), yielding a plateau age of $1236 \pm 7 \mathrm{Ma}$, an errorchron of $1226 \pm 283 \mathrm{Ma}$, and an isochron of $1244 \pm 30 \mathrm{Ma}$. We prefer the latter age to represent best the age of magnetic blocking within the eastern Namaqua Province (also preferred by Onstott et al. [1986a]), and by comparison with our INT overprint directions, the age of foreland deformation in Griqualand West. On the "Q" scale of reliability [Van der Voo, 1990], our new Namaqua Eastern Zone (NEZ) grand mean pole rates a five, failing the criterion of observed magnetic reversals (because the opposite polarity recorded by INT-2 was omitted from the mean) and similarity to younger paleopoles (Middle-Late Cambrian [Evans et al., 1998]). If INT-2 were substantiated, it would extend a hairpin loop in the Kalahari APW path that is already indicated by the Ezelfontein Formation and Umkondo igneous event (Figure 15).

[36] In the same manner that we combined lines and planes among the GFT and GSS data sets [McFadden and McElhinny, 1988], we have also computed a grand mean for the HIG and $\mathrm{HIG}^{(-)}$components (Table 2). The resulting dual-polarity paleomagnetic pole, which we name BGM for the basal Gamagara/Mapedi succession, is at $\left(02.2^{\circ} \mathrm{N}\right.$, $081.9^{\circ} \mathrm{E}, \mathrm{dp}=7.2^{\circ}, \mathrm{dm}=11.5^{\circ}$ ). On the $Q$-scale [Van der Voo, 1990], the BGM pole rates a six, failing only the numerical age criterion (more than $\pm 40 \mathrm{Myr}$ uncertainty).

[37] The Hartley lavas' modal ChRM direction is oriented moderately downward to the NW. Unfortunately, we did not find any opportunities for field tests to constrain the age of magnetization; thus it is unknown whether the ChRM is primary or an overprint. If an overprint, then paleomagnetic poles should be calculated from the mean of all 20 specimen directions in the local reference frame (Table 2), using either present coordinates $\left(\right.$ pole $17.0^{\circ} \mathrm{N}, 334.7^{\circ} \mathrm{E}, \mathrm{dp}=8.0^{\circ}, \mathrm{dm}=$ $\left.12.8^{\circ}\right)$ or tilt-corrected coordinates $\left(14.4^{\circ} \mathrm{N}, 332.4^{\circ} \mathrm{E}, \mathrm{dp}=\right.$ $8.0^{\circ}, \mathrm{dm}=12.8^{\circ}$ ), depending on the relative ages of overprinting and deformation. If the ChRM is a primary thermalremanent magnetization acquired by the lavas upon cooling, then two possibilities arise for calculation of the pole. First, if the eight adjacent flow-units were erupted in such a brief interval of time that they did not average paleosecular variation of the Earth's geomagnetic field, then we should compute a virtual geomagnetic pole (VGP) from the mean of all 20 specimens, as above. The resulting VGP could be displaced as much as $20^{\circ}$ from the time-averaged dipole axis. Second, if the eight sampled flow-units were emplaced over enough time to average paleosecular variation, then the more appropriate method would be to compute a VGP from each flow-unit, and then average these for a final paleomagnetic pole. The dispersion of VGPs can itself be used to test among these alternatives [e.g., Brock, 1971]. The angular standard deviation of our six VGPs is $18.8^{\circ}$, a reasonable value for successfully averaged paleosecular variation given the Hartley paleolatitude of $\sim 25^{\circ}$. We tentatively accept the Hartley ChRM as a primary remanence $(1928 \pm 4$ Ma [Cornell et al., 1998]), hence we have followed the latter procedure in tilt-corrected coordinates (Table 4). The resulting paleomagnetic pole ("HAR", $12.5^{\circ} \mathrm{N}, 332.8^{\circ} \mathrm{E}, K=$ $18.6, A_{95}=16.0^{\circ}$ ) rates a three on the $Q$-scale of reliability [Van der Voo, 1990], failing the criteria of statistics (fewer than 25 samples), field stability tests, reversals, and similarity to younger poles (Early Cambrian [Evans et al., 1998]).

\subsection{Paleoproterozoic Paleomagnetic Results From Kaapvaal and Zimbabwe}

[38] Although reliable and well dated paleomagnetic results from Paleoproterozoic rocks on the Kaapvaal and Zimbabwe cratons are few in number (Table 4; references in Appendix A), a generally accepted APW path from northeast Africa toward the Gulf of Guinea appears to be robust. Beginning with the low-paleolatitude Ongeluk lavas, the path migrates toward moderate paleolatitudes from the Phalaborwa Complex at 2060.6 $\pm 0.5 \mathrm{Ma}$, the Bushveld 


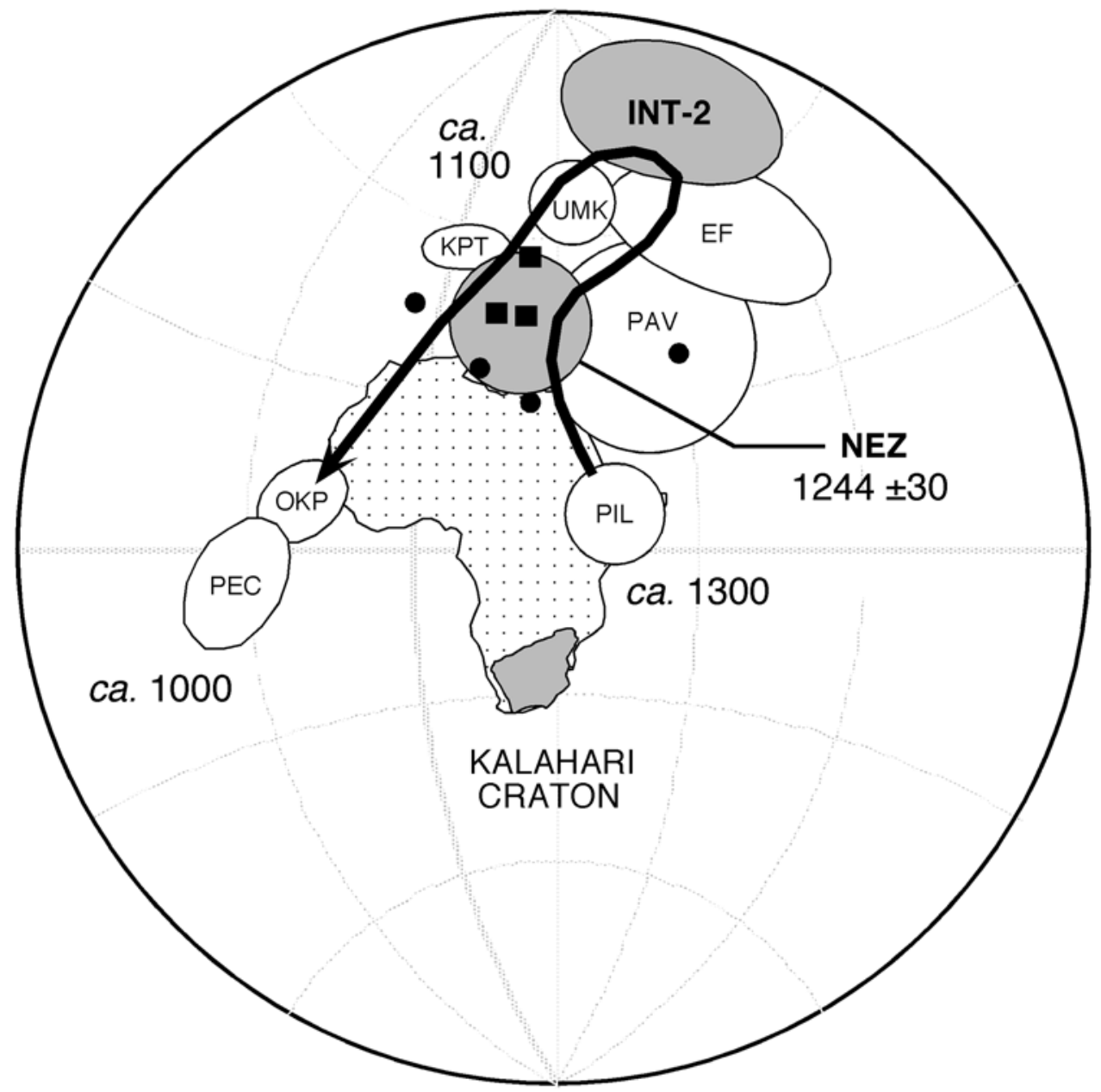

Figure 15. Mesoproterozoic apparent polar wander (APW) path for the Kalahari craton, with new poles NEZ and INT-2 (see text) shaded. Small filled circles and squares are site-mean virtual geomagnetic poles from Onstott et al. [1986a] and this study, respectively. Outline of Africa is shown merely for reference. Ages in Ma, all approximate except for the $1244 \pm 30$ Ma age for NEZ [cf. Onstott et al., 1986a]. PIL = Pilanesberg dikes [Gough, 1956], PAV = Premier kimberlite field average [Doppelhammer and Hargraves, 1994], EF = Ezelfontein Formation [lower Koras Group; Briden et al., 1979], UMK = combined Umkondo igneous event [Hargraves et al., 1994], KPT = Kalkpunt Formation [upper Koras Group; Briden et al., 1979], OKP = Okiep Norite [Onstott et al., 1986a], PEC = Port Edward Charnockite (ibid.). Note that the $\sim 1000$-Ma poles shown are merely representative of a number of results in the general vicinity [cf. Onstott et al., 1986a].

Complex at about the same age, and the Vredefort Complex at $2023 \pm 4$ Ma. Finally, the APW path continues westward to the 1800-1900-Ma Mashonaland and neighboring poles.

[39] Depending on the age of the Gamagara/Mapedi succession, our new results indicate varying complexities of Kaapvaal's Paleoproterozoic APW. If the sub-Gamagara/ Mapedi unconformity and paleoweathering profile is older than the Bushveld Complex, as suggested by recent stratigraphic correlations across Griqualand West and into the Transvaal [Beukes et al., 2002], then our results indicate a single, monotonic swath of APW between Ongeluk and Bushveld/Vredefort times. The swath would continue monotonically westward to encounter the Mashonaland group of poles at 1800-1900 Ma (solid curve in Figure 16). However, if the sub-Gamagara/Mapedi unconformity were nearer to its younger direct age limit of $1928 \pm 4 \mathrm{Ma}$ [Cornell et al., 1998], as suggested by traditional correla- tions of the basal Olifantshoek succession with the postBushveld Waterberg Group [e.g., Beukes, 1986; Cheney et al., 1990], then a more complicated APW path would be implied, oscillating $\sim 250^{\circ}$ between the Ongeluk, Phalaborwa-Bushveld, BGM, and Hartley-Mashonaland poles (dashed curve in Figure 16). Of course, the 50-100 Myr between each period of reliable results could allow such large APW swings in the context of "normal" plate velocities, but we provisionally prefer the far simpler APW path suggested by a pre-2060 Ma sub-Gamagara/Mapedi unconformity [Beukes et al., 2002].

\subsection{Implications for Atmospheric Oxidation at 1.9-2.1 Ga}

[40] Our results can help constrain the amount of free atmospheric oxygen in Paleoproterozoic time. The positive conglomerate test on hematitized ore pebbles within the 
Table 4. Selected Early Paleoproterozoic Paleomagnetic Poles From the Kaapvaal-Kalahari Craton ${ }^{\mathrm{a}}$

\begin{tabular}{|c|c|c|c|c|c|c|c|c|c|c|}
\hline Rock unit & Code & Age (Ma) & Reference $^{\mathrm{b}}$ & $\mathrm{N}$ & Latitude, ${ }^{\circ} \mathrm{N}$ & Longitude, ${ }^{\circ} \mathrm{E}$ & $K$ & dp, deg & $\mathrm{dm}, \mathrm{deg}$ & Pmag ref. \\
\hline \multicolumn{11}{|c|}{ Most Reliable Poles } \\
\hline Ongeluk lava & ONG & $2222 \pm 13^{\mathrm{c}}$ & 1 & 22 & -00.5 & 100.7 & 38.3 & 5.3 & 5.3 & 2 \\
\hline Basal Gamagara/Mapedi & BGM & $2060-2200^{\mathrm{d}}$ & 3 & $32 *$ & 02.2 & 081.9 & - & 7.2 & 11.5 & this study \\
\hline Phalaborwa 1 & PB1 & $2060.5 \pm 0.6$ & 4 & 11 & 35.9 & 044.8 & - & 6.9 & 10.5 & 5 \\
\hline Bushveld main + upper & BVMU & $2061 \pm 27$ & 6 & 70 & 11.5 & 027.2 & 19.0 & 4.0 & 4.0 & $7-10^{\mathrm{e}}$ \\
\hline Vredefort VGP & VRED & $2023 \pm 4$ & 11 & 10 & 22.3 & 040.7 & - & 11.6 & 15.7 & $12,13^{\mathrm{e}}$ \\
\hline Mashonaland sills & MASH & $1830 \pm 230$ & 14 & 29 & 07.6 & 338.2 & 28.3 & 5.1 & 5.1 & 15,16 \\
\hline \multicolumn{11}{|c|}{ Other Poles Shown in Figure 16} \\
\hline Witwatersrand overprint & WITS & $1945 \pm 40 ?$ & 17 & 17 & 19.1 & 045.6 & 22.1 & 7.8 & 7.8 & 17 \\
\hline Limpopo metam. "A" & LMA & $1950-1980 ?$ & 18 & 21 & 26.1 & 022.3 & - & 7.9 & 10.3 & 18 \\
\hline Great Dyke Extensions & GDE & $1895 \pm 73 ?$ & 18 & 7 & 19.9 & 359.6 & - & 11.1 & 15.0 & 19,20 \\
\hline Sand River Dykes & SRD & $1876 \pm 68 ?$ & 18 & 6 & 02.3 & 009.1 & - & 10.3 & 10.3 & $18^{\mathrm{e}}$ \\
\hline Phalaborwa 2 & PB2 & $1800-1900 ?$ & - & 10 & 04.2 & 357.8 & 31.2 & 8.8 & 8.8 & $5^{\mathrm{e}}$ \\
\hline Hartley lava & HAR & $1928 \pm 4$ & 21 & 6 & 12.5 & 332.8 & 18.6 & 16.0 & 16.0 & this study \\
\hline Richtersveld Province & RICH & ca. $1750 ?$ & 22 & 9 & -42.1 & 307.3 & 12.1 & 15.4 & 15.4 & 22 \\
\hline Limpopo metam. "B" & LMB & ??? & - & 8 & -45.7 & 279.2 & - & 8.1 & 16.2 & 18 \\
\hline
\end{tabular}

${ }^{\mathrm{a}}$ Abbreviations: $N$, number of sites, or specimens (*); K, Fisher's [1953] precision parameter in pole space; dp, dm, semiaxes of $95 \%$ confidence cone about mean.

${ }^{\mathrm{b}}$ References: (1) Cornell et al., 1996; (2) Evans et al., 1997; (3) Beukes et al., 2002; (4) Reischmann, 1995; (5) Morgan and Briden, 1981; (6) Walraven et al., 1990; (7) Hattingh, 1986a; (8) Hattingh, 1986b; (9) Hattingh, 1989; (10) Hattingh and Pauls, 1994; (11) Kamo et al., 1996; (12) Hargraves, 1970; (13) Hart et al., 1995; (14) Compston and McElhinny, 1975; (15) McElhinny and Opdyke, 1964; (16) Bates and Jones, 1996; (17) Layer et al., 1988; (18) Morgan, 1985; (19) Jones et al., 1975; (20) McElhinny and Cowley, 1978; (21) Cornell et al., 1998; (22) Onstott et al., 1986b.

${ }^{c}$ Note that Bau et al. [1999] interpret an age of $\sim 2400$ Ma for the Ongeluk-Hekpoort volcanics.

${ }^{\mathrm{d}}$ According to the simplest correlations; see text for details.

eur recalculation (see Appendix A).

Doornfontein Conglomerate Member implies that supergene hematitic oxidation occurred prior to Gamagara deposition, validating the basis for earlier calculations of high $\mathrm{pO}_{2}$ from the Wolhaarkop paleosol by Holland and Beukes [1990]. Note that our indications of widespread Mesoproterozoic remagnetization due to hematite recrystallization should not invalidate the previous calculations of $\mathrm{pO}_{2}$, because the neoformed hematite has simply regrown without addition of Fe [Holland and Beukes, 1990]. The paleolatitude of $26+8 /$ $-7^{\circ}$ calculated from our results is concordant with the commonly noted low-latitude range of modern laterites [Thomas, 1994, p. 91; but see also Taylor et al., 1992].

[41] Our BGM pole can also help constrain the age of Paleoproterozoic atmospheric oxygen enrichment. The new pole is similar to that from the Ongeluk lavas [Evans et al., 1997], but widely separated from our HAR result from the overlying Hartley lavas. Although our new HAR result can only be considered tentatively, these observations further support the stratigraphically based hypothesis of a major unconformity within the presently defined Olifantshoek Supergroup, and consequently less temporal significance ascribed to the sub-Gamagara/Mapedi unconformity (Figures 1 and 2) [Beukes et al., 2002]. In addition, a far simpler APW path arises from the new correlations as compared with the old (Figure 16). Our study thus supports a substantial atmospheric oxygen concentration prior to 2.06 $\mathrm{Ga}$, the age of the Bushveld complex intruding Gamagaracorrelative strata in the Pretoria region, according to these new stratigraphic correlations. Rye and Holland [1998], summarizing the global paleosol database, proposed a similar age for large-scale enrichment of atmospheric free oxygen, although their quoted age uncertainties permitted the event to have occurred as late as $\sim 1.9 \mathrm{Ga}$. Note that although our results legitimize earlier calculations of minimum Paleoproterozoic $\mathrm{pO}_{2}$ levels [Holland and Beukes, 1990], the controversial issue of maximum constraints upon
Archean atmospheric oxygen content [e.g., Ohmoto, 1996; Rye and Holland, 1998; Kirschvink et al., 2000] remains unaffected by our data.

\subsection{Early Paleoproterozoic Global Evolution}

[42] Our preferred age of Drakenstein-Wolhaarkop lateritization, between 2.2 and $2.06 \mathrm{Ga}$, complements earlier data concerning early Paleoproterozoic supercontinents [Aspler and Chiaranzelli, 1998], low-latitude glaciations [Evans et al., 1997], atmospheric oxygen enrichment [Rye and Holland, 1998], carbon-isotope anomalies [Karhu and Holland, 1996], and the evolution of eukaryotes [Kirschvink et al., 2000]. All of the world's Paleoproterozoic glaciogenic deposits are constrained in age between 2.45 and $2.2 \mathrm{Ga}$ [Aspler and Chiaranzelli, 1998], when two bursts of voluminous mafic volcanism may manifest the protracted breakup of Kenorland, possibly Earth's first supercontinent [Aspler and Chiaranzelli, 1998; Evans, 1999]. Although this supercontinent lacks a paleomagnetic reconstruction, it was apparently long-lived, and may have created an underlying superplume through isolation of its underlying mantle from the cooling effects of subducted slabs [see Anderson, 1994]. It would then have migrated to the equator via true polar wander and become elevated in the same sense as today's Africa following Pangea's breakup [Anderson, 1982]. The low paleolatitudes of the Ongeluk lavas [Evans et al., 1997] and subsequent lateritic weathering surface (the present study) support this model of near-equatorial cratonic uplift following plume-related supercontinental fragmentation.

[43] A low-latitude supercontinent may be the precondition for "Snowball Earth" glaciation, due to the absence of a silicate-weathering negative feedback, which would otherwise regulate atmospheric $\mathrm{CO}_{2}$ levels during ice ages [Hoffman and Schrag, 2000]. Evolution of eukaryotes may have immediately followed one or more Paleoproterozoic Snowball Earth episodes [Kirschvink et al., 2000]. As 


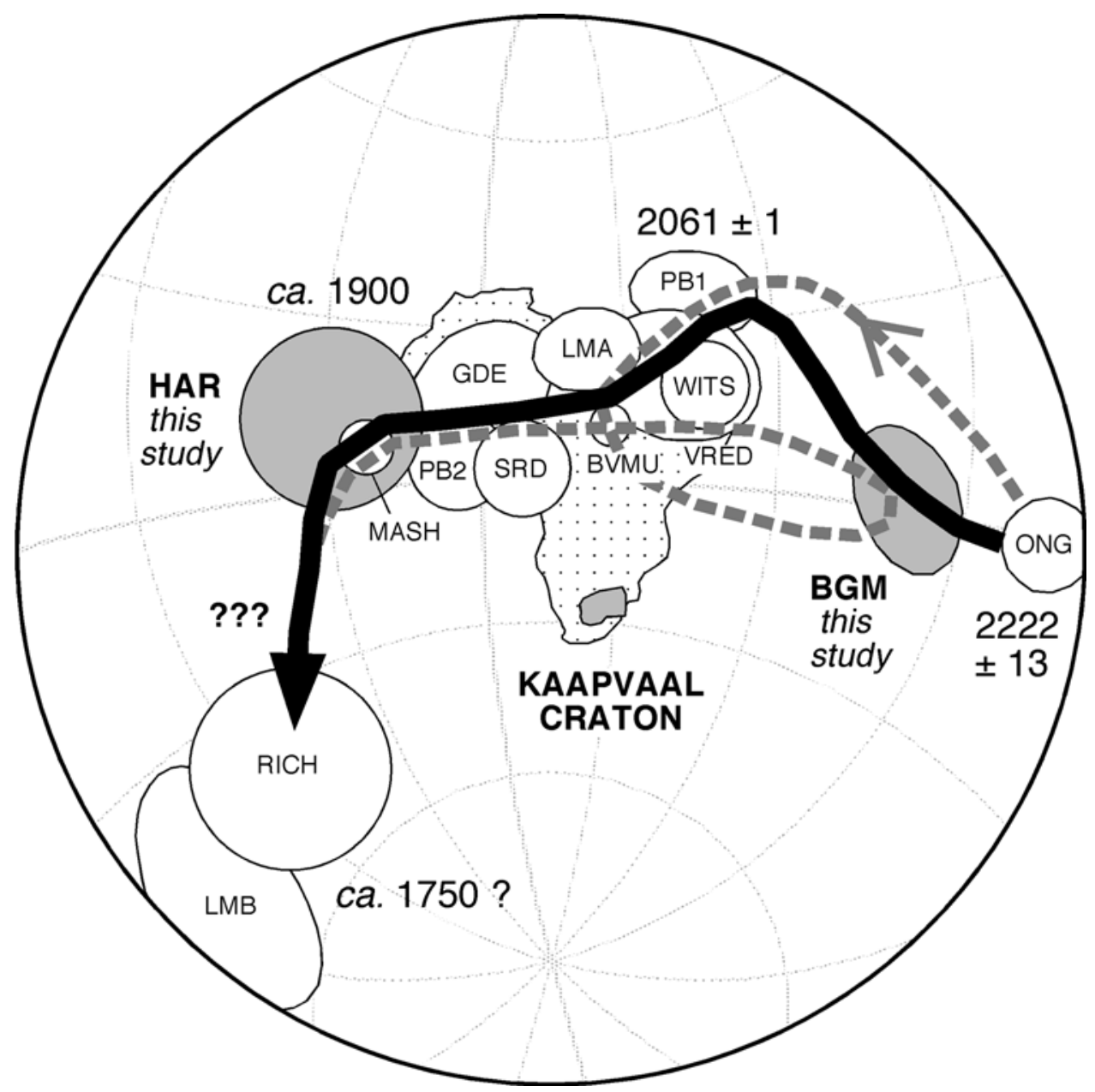

Figure 16. Paleoproterozoic APW path for the Kaapvaal craton, with new poles BGM (HIG component from Sishen and Beeshoek) and HAR (Hartley lava ChRM) shaded. Outline of Africa shown merely for reference. Swaths show two different age possibilities for the basal Gamagara/Mapedi Formation: solid = preferred, based on new stratigraphic correlations of Beukes et al. [2002]; dashed = less preferred, according to traditional correlations [e.g., Beukes, 1986]. ONG = Ongeluk lavas, PB1 = Phalaborwa Group 1, WITS = Witwatersrand overprint VRED = Vredefort VGP, BVMU = Bushveld Main and Upper Zones combined, LMA = Limpopo metamorphics A component, GDE = Great Dyke extensions into Limpopo belt, SRD = Sand River dikes, $\mathrm{PB} 2=$ Phalaborwa Group 2, MASH $=$ Mashonaland sills, RICH $=$ Richtersveld Province, LMB = Limpopo metamorphics B component. For details of these poles and discussion of their ages, see Table 4 and Appendix A.

stated above, our results support a 2200-2060-Ma age for the Drakenstein-Wolhaarkop lateritization [Beukes et al., 2002], placing it in temporal proximity to these earlier events and also the remarkable "Lomagundi" carbon-isotope excursion [Karhu and Holland, 1996]. A simplistic model incorporating all of these data could include a cyanobacterial bloom following Snowball-Earth glaciation, concomitant with efficient burial of organic carbon on the subsiding passive margins of Kenorland's fragments (analogous to Neoproterozoic Rodinia's breakup; see Hoffman et al. [1998]). Such an event would pump $\mathrm{O}_{2}$ into the atmosphere, create laterites on exposed low- to moderatelatitude cratonic fragments such as Kaapvaal, and drive marine ${ }^{13} \mathrm{C}$ isotopes extremely positive. However, such a model would also predict further glaciation due to $\mathrm{CO}_{2}$ drawdown, and there is no evidence of a Paleoproterozoic ice age younger than $2.2 \mathrm{Ga}$.
[44] As an alternative, perhaps it was merely the proportion of organic carbon burial, rather than the total amount of carbon burial, that produced the Lomagundi carbon-isotope excursion between 2.2 and $2.06 \mathrm{Ga}$. That may have been due to the eustatic drowning of continental shelves (except highstanding Kaapvaal) as Kenorland's fragmentation progressed.

\section{Conclusions}

[45] Our results from the Gamagara/Mapedi red beds, as well as the paleoweathered zone beneath these sediments, support previous models of an oxidated early Paleoproterozoic hydro-atmosphere, including the effects of lateritic weathering, fluvial transport of hematitic ore pebbles, and deposition of red beds. These events occurred prior to 1.93 $\mathrm{Ga}$, the age of Hartley volcanism occurring higher in the stratigraphic succession [Cornell et al., 1998]. If contacts 
between the studied units and the dated lavas were conformable, as preferred by traditional interpretations, then our newly determined BGM paleomagnetic pole at $\left(02.2^{\circ} \mathrm{N}\right.$, $081.9^{\circ} \mathrm{E}, \mathrm{dp}=7.2^{\circ}, \mathrm{dm}=11.5^{\circ}$ ) would indicate a rather tortuous Paleoproterozoic APW path and substantial drift of the Kalahari craton relative to the geomagnetic reference frame between 2.2 and $1.8 \mathrm{Ga}$. Alternatively, if the Gamagara/Mapedi succession predates the Bushveld Complex as suggested by regional stratigraphic correlations of the subGamagara paleoweathering profile, then a rather simple APW path emerges. This alternative, which we prefer, in turn implies that the well documented oxidative paleoweathering and fluvial transport of the Gamagara/Mapedi substrate occurred prior to $2060 \mathrm{Ma}$.

\section{Appendix A: Review of Paleoproterozoic Paleomagnetic Results From the Kaapvaal and Zimbabwe Cratons}

\section{A1. Ongeluk Lavas}

[46] Following an earlier study of the correlative Hekpoort volcanics by Briden [1976], Evans et al. [1997] sampled 20 flow-units of Ongeluk basaltic-andesite, observing one ancient magnetic component with a shallow-west (one site shallow-ESE) direction. A breccia test at one locality indicated wide dispersion of directions among a suite of individually sampled, broken pillow fragments entrained in the hyaloclastite. On this basis, Evans et al. [1997] interpreted the shallow east-west direction as a primary thermal-remanent magnetization, with a reliability value of $Q=7$ [Van der Voo, 1990]. The Ongeluk lavas are universally correlated with the Hekpoort andesite in Transvaal, and the two formations have been dated by a variety of methods; Cornell et al. [1996] preferred their $\mathrm{Pb} / \mathrm{Pb}$ date of $2222 \pm 13 \mathrm{Ma}$, from the Ongeluk lavas, as the best estimate of the age of extrusion. Alternatively, Bau et al. [1999] interpret these ages to represent secondary alteration, and an interpreted diagenetic $\mathrm{Pb} / \mathrm{Pb}$ age of $2394 \pm 26 \mathrm{Ma}$ on the overlying Mooidraai Dolomite to represent a true minimum for the Ongeluk lavas. Further isotopic studies of the Transvaal succession will be necessary to resolve this discrepancy.

\section{A2. Phalaborwa Complex}

[47] Two groups of paleomagnetic directions have been found by Morgan and Briden [1981] (superseding Briden [1976]). Although the groups are not uniformly related to lithology, in most instances the dual-polarity "Group 2" is associated with a NE-trending dolerite dike swarm that postdates the complex. A baked-contact test between rocks of the main complex and one of the younger dikes implies a primary remanence for the latter and a predike remanence for the former [Morgan and Briden, 1981]. The "Group 1" remanence exists within a range of coarse-grained lithologies, which are considered to have intruded in several stages [Fourie and de Jager, 1986]. We consider, then, that its paleomagnetic pole $\left(35.9^{\circ} \mathrm{N}, 044.8^{\circ} \mathrm{E}, \mathrm{dp}=6.9^{\circ}, \mathrm{dm}=\right.$ $10.5^{\circ}$ ) successfully averages out geomagnetic secular variation. As for Group 2, we have recalculated the pole according to a mean of virtual geomagnetic poles (VGPs) computed from the 10 site means using Fisher's [1953] statistics in pole-space: $\left(04.2^{\circ} \mathrm{N}, 357.8^{\circ} \mathrm{E}, K=31.2\right.$,
$A_{95}=8.8^{\circ}$ ). The main phases of the Phalaborwa complex have been dated by U-Pb methods on uranothorianite and baddeleyite, at $2047+11 /-8 \mathrm{Ma}$ [Eriksson, 1984] and $2060.6 \pm 0.5 \mathrm{Ma}$ [Reischmann, 1995]. We interpret the latter age as the best current estimate for the age of the Group 1 remanence. The Group 2 pole is similar to those from the Sand River and Sebanga dikes, presumably $\sim 1800-1900$ $\mathrm{Ma}$ in age (see below).

\section{A3. Bushveld Complex}

[48] Following the early study of Gough and van Niekerk [1959], more detailed paleomagnetic work, mainly using AF but also some thermal demagnetization, on the so-called "main" [Hattingh, 1986a, 1986b; Hattingh and Pauls, 1994], "critical" [Hattingh, 1986c], and "upper" [Hattingh, 1989; Hattingh and Pauls, 1994] zones of the layered mafic suite have yielded generally consistent results. Results from within each of the eastern and western outcrop areas of the Main Zone demonstrate a prefold characteristic remanence [Hattingh, 1986a, 1986b], and directional clustering between these two groups also increases upon tilt-correction of the Bushveld structural basin. Results from the main zone in the northern (Potgietersrus) limb of the complex [Hattingh and Pauls, 1994] also group better with those from the other regions after tilt restoration. From the upper zone of the layered suite, stable magnetic behavior characterizes seven sites distributed throughout the complex's southern region, yielding a paleomagnetic pole similar to those from the main zone [Hattingh, 1989]. Inconsistent and scattered magnetic directions characterize the upper zone from more northerly Villa Nora inlier [Hattingh and Pauls, 1994]. Magnetic remanence from eight sites in the critical zone is significantly shallower than all of the other Bushveld directions, and may indicate substantial APW during multiphase intrusion [Hattingh, 1986c].

[49] Given the agreement among all sites in the main and upper zones (except from the ill-behaved Villa Nora inlier), we have combined the data from these 70 sites to compute a grand mean paleomagnetic pole for this portion of the layered mafic suite. Because the sites are distributed over an area of $50,000 \mathrm{~km}^{2}$, we first compute the VGP at each site, then combine all 70 VGPs. Our resulting tilt-corrected, dual-polarity pole is at $\left(11.5^{\circ} \mathrm{N}, 027.2^{\circ} \mathrm{E}, K=19.0, A_{95}=\right.$ $4.0^{\circ}$ ), within uncertainty of each of the tilt-corrected subpoles [Hattingh, 1986a, 1986b, 1989; Hattingh and Pauls, 1994].

[50] The age of the Bushveld Complex is generally considered to be $\sim 2050-2060 \mathrm{Ma}$, but there has been much variation in isotopic results [Walraven et al., 1990]. The most recent, precise U-Pb determinations yield ages of $2098.6 \pm$ $3.1 \mathrm{Ma}$ (multigrain analyses of cassiterite [Gulson and Jones, 1992]) and $2054.4 \pm 1.8 \mathrm{Ma}$ (zircon Pb-evaporation [Walraven and Hattingh, 1993]) for late-stage granites intruding all other phases of the complex. A compilation of available $\mathrm{Rb}-\mathrm{Sr}$ data from the layered mafic suite results in a 33-point isochron with an age of $2061 \pm 27 \mathrm{Ma}$ [Walraven et al., 1990]. This result is consistent with the younger of the two granite ages cited above, and also with recent plume models for the origin of the bimodal complex as a whole [e.g., Hatton and Schweitzer, 1995]. We prefer this less precise age for the acquisition of magnetic remanence, because the Bushveld's enormous size and mafic-ultramafic composi- 
tions could imply slow cooling from elevated emplacement temperatures.

\section{A4. Vredefort Structure}

[51] Hargraves [1970] initiated paleomagnetic study of the Vredefort complex, sampling from a range of lithologies within the central core and outer, overturned "collar." Results from bronzite-granophyric ring-dikes, which postdate the structural overturning, show a north-down magnetization. The Losberg Complex, lying at the little-deformed northern limit of the Vredefort structure and coeval with the Bushveld Complex $(2041 \pm 41 \mathrm{Ma}, \mathrm{Rb}-\mathrm{Sr}$ whole rock and mineral isochron [Coetzee and Kruger, 1989]), yielded similar paleomagnetic directions from a single site [Hargraves, 1970]. In addition, magnetization of the Rietfontein Complex, intruded into the overturned "collar," restores to this same north-down direction after rotation of the overturned rocks to their paleohorizontal orientation; this suggests that the Rietfontein Complex is of similar age to the others, yet predates the Vredefort structure [Hargraves, 1970]. The same conclusion can be drawn from magnetization of eight samples from the Lindequesdrift intrusion, although a $2163 \pm 31 \mathrm{Ma},{ }^{40} \mathrm{Ar} /{ }^{39} \mathrm{Ar}$ age on hornblende could suggest a substantially older age for that unit [Hargraves, 1987]. Finally, Hart et al. [1995] reported paleomagnetic data from 16 sites within the granitic basement in the core of the structure. One of their sites is in close proximity to the pseudotachylite sample that yielded a U-Pb zircon age of $2023 \pm 4 \mathrm{Ma}$ [Kamo et al., 1996]. A postimpact granite in the central core has been dated at $2017 \pm 5$ Ma (SHRIMP zircon [Gibson et al., 1997]). Given the above constraints, we combine the paleomagnetic data of Hargraves [1970] and Hart et al. [1995], from the bronzite granophyre and basement complex, respectively, to generate a mean direction of $\left(\mathrm{D}=015.8^{\circ}, \mathrm{I}=58.4^{\circ}, \alpha_{95}=10.6^{\circ}, \mathrm{N}=\right.$ 10 sites $)$ and mean VGP at $\left(22.3^{\circ} \mathrm{N}, 040.7^{\circ} \mathrm{E}, \mathrm{dp}=11.6^{\circ}\right.$, $\left.\mathrm{dm}=15.7^{\circ}\right)$. It is uncertain whether this remanence was acquired over long enough of an interval to average geomagnetic secular variation sufficiently.

\section{A5. Witwatersrand Overprint}

[52] Layer et al. [1988] analyzed specimens from shales within the Witwatersrand Supergroup, in a regional study of surface outcrops and borehole cores across the southern Kaapvaal craton. Negative fold tests were obtained at both the regional and local scale. K-Ar dating of clay fractions smaller than $2 \mu \mathrm{m}$ yielded an age of $1945 \pm 40 \mathrm{Ma}$, interpreted by Layer et al. [1988] to represent the time of magnetic overprinting. The corresponding paleomagnetic pole $\left(19.1^{\circ} \mathrm{N}, 045.6^{\circ} \mathrm{E}, K=22.1, A_{95}=7.8^{\circ}\right)$ is similar to Bushveld, Vredefort, and Limpopo poles, consistent with the K-Ar clay age, and perhaps indicates a Bushveld- or Vredefort-related origin for the regional overprint.

\section{A6. Limpopo Metamorphics and Great Dyke Extensions}

[53] Jones et al. [1975] examined southerly extensions of the Great Dyke and its two parallel satellites, the Umvimeela and East Dykes. These extensions lie within the metamorphosed northern zone of the Limpopo belt and consistently show a magnetization direction that differs from those observed within the undeformed sectors of these dikes. Despite a lack of field stability tests, Jones et al. [1975] quite reasonably interpreted this southerly magnetization as an overprint acquired during Limpopo deformation. McElhinny and Cowley [1978] computed a mean direction from the seven sites of Jones et al. [1975], and thence a paleomagnetic pole at $\left(19.9^{\circ} \mathrm{N}, 359.6^{\circ} \mathrm{E}, \mathrm{dp}=\right.$ $\left.11.1^{\circ}, \mathrm{dm}=15.0^{\circ}\right)$. The age of this overprint may be inferred from regionally averaged isotopic dates from the Limpopo belt, mainly $\sim 1950-1980 \mathrm{Ma}$ (see below), but it could also have occurred outside this age range. Indeed, Morgan [1985] assigned an age of $1895 \pm 73 \mathrm{Ma}$, an average of five $\mathrm{Rb}-\mathrm{Sr}$ dates from nearby gneisses, to the Great Dyke extensions' magnetization.

[54] Following the preliminary report by Morgan and Briden [1981], Morgan [1985] described fully his paleomagnetic results from the Botswanan and South African sectors of the Limpopo belt. Aside from a northerly upward component coincident with the present local field direction, two ancient components were observed: a north-down direction ("A") from 21 sites (pole $26.1^{\circ} \mathrm{N}, 022.3^{\circ} \mathrm{E}$, $\left.\mathrm{dp}=7.9^{\circ}, \mathrm{dm}=10.3^{\circ}\right)$, and a shallow-northeast direction ("B") from eight sites (pole $-45.7^{\circ} \mathrm{N}, 279.2^{\circ} \mathrm{E}, \mathrm{dp}=8.1^{\circ}$, $\left.\mathrm{dm}=16.2^{\circ}\right)$. Most directions were from endpoints of $\mathrm{AF}$ demagnetization, although in a few cases vector-subtraction was used to isolate components. No field tests were performed to constrain the ages of the two directions. Both components exhibited dual-polarity, sometimes coexisting within single specimens. Localities with the "B" direction are concentrated toward the center of the orogen, although a few sites extend toward its margins. There is no obvious correlation between regional distributions of the " $A$ " and "B" components with variations in $\mathrm{Rb}-\mathrm{Sr}$ isotopic ages (most commonly 1950-1980 Ma [Morgan, 1985]).

\section{A7. Sand River Dykes}

[55] Morgan [1985] also collected samples from six posttectonic Sand River Dykes at a single locality within the Southern Marginal Zone of the Limpopo belt in South Africa. One dike showed reverse polarity relative to the other five. Under the assumption that this dual-polarity remanence is primary-although no field tests were performed to support this inference-the paleomagnetic pole should be the mean of six VGPs, one from each sampled dike. We calculate a mean of Sand River VGPs at $\left(02.3^{\circ} \mathrm{N}, 009.1^{\circ} \mathrm{E}\right.$, $K=43.4, A_{95}=10.3^{\circ}$ ). From the same sampling locality, Barton [1979] conducted eight whole rock $\mathrm{Rb}-\mathrm{Sr}$ analyses on a single dike, determining an age of $1899 \pm 107 \mathrm{Ma}$. Further analyses, one from each of three parallel dikes, yielded higher $\mathrm{Rb}$ concentrations; one was better aligned with the original eight and was therefore included in a final regression of $1876 \pm 68 \mathrm{Ma}$ (Barton, 1979; quoted by Morgan [1985]).

\section{A8. Barberton Region NW Trending Dykes}

[56] Layer et al. [1998] reported paleomagnetic and ${ }^{40} \mathrm{Ar} /{ }^{39} \mathrm{Ar}$ results from an unnamed but prominent dolerite swarm intruding the granite-greenstone basement of the Kaapvaal craton near Barberton [Hunter and Reid, 1987]. The paleomagnetic directions from both dykes and country rocks (Nelshoogte Pluton) show moderate scatter among two polarities of a steep remanence direction ("B") [Layer et al., 1998]. Although rigorous baked-contact tests were 
not reported, existence of a stable, distinct country rock remanence supports the notion of a primary dyke remanence. Layer et al. [1998] did not compute a combined "B" pole for the dykes and remagnetized country rock, and the appearance of "B" within only one or two specimens from the majority of country rock sites renders robust statistical combination of all the results difficult. Two dykes yielded total integrated whole rock ${ }^{40} \mathrm{Ar} /{ }^{39} \mathrm{Ar}$ ages of $1902 \pm 6$ and $1876 \pm 6 \mathrm{Ma}$, respectively. Geochemical analyses of NW-trending dolerites in this region, however, fall into two distinct subsets [Hunter and Halls, 1992], suggesting that there may be more than one intrusive event in this region. Indeed, many of the dykes appear truncated by the basal Transvaal nonconformity $(\sim 2700 \mathrm{Ma})$, whereas a few with similar NW trend penetrate into that sedimentary succession [Hunter and Reid, 1987]. Steep magnetic inclinations characterize 2780-Ma volcanic successions on the Kaapvaal craton [Wingate, 1998], so the moderately large degree of scatter and non-antipolarity among the paleomagnetic results of Layer et al. [1998] may be partly explained by the possibility their data set records the influence of two distinct, steeply oriented magnetization events.

\section{A9. Mashonaland Sills}

[57] Following the original study by McElhinny and Opdyke [1964], this igneous province has been studied further by Bates and Jones [1996]. The latter study confirmed the original paleopole, of dual-polarity (our recalculated mean of 29 unit-weighted VGPs at $07.6^{\circ} \mathrm{N}, 338.2^{\circ} \mathrm{E}$, $K=28.3, A_{95}=5.1^{\circ}$ ), and supplemented this with a baked contact test of one sill (MS15) intruded by a NNE trending dike bearing a magnetic remanence similar to and thus correlated with the Sebanga swarm (see below). Unfortunately, the Mashonaland igneous province is imprecisely dated, at $1830 \pm 230 \mathrm{Ma}[\mathrm{Rb}-\mathrm{Sr}$ whole rock data of Compston and McElhinny, 1975; recalculated by Wilson et al., 1987]. The Mashonaland pole is nonetheless included as one of the "most reliable" in Table 4, because of its high paleomagnetic reliability and the prospect of a more precise age determination (D. Jones and M. Wingate, personal communication). Paleomagnetism of the NNWtrending Sebanga, Crystal Spring, and Bubi swarms from southern Zimbabwe yields shallower NW-down and SE-up directions that, at least for the Crystal Spring and Bubi samples, could well be primary [Jones et al., 1975]. Nonetheless, the two polarities are not quite antipodal, and the intrusion ages are not well known [Wilson et al., 1987; Mushayandebvu et al., 1995; Bates and Jones, 1996].

\section{A10. Waterberg Sediments}

[58] Studied paleomagnetically by Jones and McElhinny [1967], red beds of the Waterberg and Soutpansberg Groups have yielded a range of directions that vary in an apparently consistent manner through the composite stratigraphic column. McElhinny [1968] arranged the site mean directions into five groups, the oldest three of which were abbreviated W1-W3 by Morgan and Briden [1981] and many subsequent workers. Morgan and Briden [1981] also analyzed six samples from the Rust der Winter outlier of red beds, and the resulting pole lies between $\mathrm{W} 1$ and W2. Unfortunately, no field tests were undertaken in either of the Waterberg studies, and numerical ages of the Waterberg and Soutpansberg are highly uncertain [cf. Cheney et al., 1990].

\section{A11. Richtersveld Province}

[59] Superseding an earlier study by Piper [1975], Onstott et al. [1986b] sampled from Haib metavolcanics and the subsequently intruding Vioolsdrif batholithic suite. Aside from magnetic components interpreted as Mesoproterozoic or Mesozoic overprints, a dual-polarity remanence was observed within the metavolcanics (before tilt-correction), as well as early and late phases of the igneous suite. The combined pole $\left(42.1^{\circ} \mathrm{S}, 307.3^{\circ} \mathrm{E}, K=12.1, A_{95}=15.4^{\circ}\right)$ may date from about $1900-1880 \mathrm{Ma}$, or about $1840-1770 \mathrm{Ma}$, depending on alternative models for batholithic intrusion and postigneous cooling throughout the province [cf. Onstott et al., 1986b]. Regardless, the wide separation between this pole and most other Paleoproterozoic results from the Kalahari craton (except Limpopo "B") suggests either: an exotic status of the Richtersveld Province relative to the Kaapvaal craton at $1900-1750 \mathrm{Ma}$, as preferred by Onstott et al. [1986b], or moderate to rapid APW toward the Richtersveld pole from the Hartley/Mashonaland/Sand River/Sebanga/Phalaborwa-2 cluster.

[60] Acknowledgments. We thank H. Wiggering for field assistance, and the managements of Sishen, Rooinekke, and Beekshoek Mines for permission to collect samples. The Department of Geology at RAU provided logistical support for field work. D.Y. Sumner and Tiekie Beukes helped with the sample analyses. This project was supported by NSF grant EAR94-18523 (USA) and the NRF Open Research Program (South Africa), and DADE was supported by NSF Graduate and ARC Postdoctoral Research Fellowships. Data reduction was aided by the Paleomag and GMAP programs, respectively administered by Craig Jones and Trond Torsvik. Jens Gutzmer and Dai Jones provided insightful comments, and we thank Rob Hargraves and Pierrick Roperch for their constructive reviews. Tectonics Special Research Centre contribution 157.

\section{References}

Altermann, W., and I. W. Hälbich, Structural history of the southwestern corner of the Kaapvaal Craton and the adjacent Namaqua realm: New observations and a reappraisal, Precambrian Res., 52, 133-166, 1991.

Anderson, D. L., Hotspots, polar wander, Mesozoic convection and the geoid, Nature, 297, 391-393, 1982.

Anderson, D. L., Superplumes or supercontinents?, Geology, 22, 39-42, 1994.

Aspler, L. B., and J. R. Chiaranzelli, Two Neoarchean supercontinents? Evidence from the Paleoproterozoic, Sediment. Geol., 120, 75-104, 1998.

Bates, M. P., and D. L. Jones, A palaeomagnetic investigation of the Mashonaland dolerites, north-east Zimbabwe, Geophys. J. Int., 126, 513524, 1996

Bau, M., R. L. Romer, V. Lüders, and N. J. Beukes, Pb, O, and C isotopes in silicified Mooidraai dolomite (Transvaal Supergroup, South Africa): Implications for the composition of Paleoproterozoic seawater and 'dating' the increase of oxygen in the Precambrian atmosphere, Earth Planet. Sci. Lett., 174, 43-57, 1999.

Bekker, A., K. A. Eriksson, A. J. Kaufman, J. A. Karhu, and N. J. Beukes, Paleoproterozoic record of biogeochemical events and ice ages, Geol. Soc. Am. Abstr. Programs, 31(7), A-487, 1999.

Beukes, N. J., The Transvaal sequence in Griqualand West, in Mineral Deposits of Southern Africa, vol. I, edited by C. R. Anhaeusser and S. Maske, pp.819-828, Geol. Soc. S. Afr., Johannesburg, 1986.

Beukes, N. J., and C. A. Smit, New evidence for thrust faulting in Griqualand West, South Africa: Implications for stratigraphy and the age of red beds, S. Afr. J. Geol., 90, 378-394, 1987.

Beukes, N. J., H. Dorland, J. Gutzmer, M. Nedachi, and H. Ohmoto, Tropical laterites, life on land, and the history of atmospheric oxygen in the Paleoproterozoic, Geology, 30, 491-494, 2002.

Briden, J. C., Application of palaeomagnetism to Proterozoic tectonics, Philos. Trans. R. Soc. London, Ser. A, 280, 405-416, 1976.

Briden, J. C., B. A. Duff, and A. Kröner, Palaeomagnetism of the Koras Group, northern Cape Province, South Africa, Precambrian Res., 10, $43-57,1979$. 
Brock, A., An experimental study of palaeosecular variation, Geophys. J. R. Astron. Soc., 24, 303-317, 1971.

Buick, I. S., R. Uken, P. L. Gibson, and T. Wallmach, High- $\delta^{13} \mathrm{C}$ Paleoproterozoic carbonates from the Transvaal Supergroup, South Africa, Geology, 26, 875-878, 1998 .

Cheney, E. S., J. M. Barton Jr., and G. Brandl, Extent and age of the Soutpansberg sequences of southern Africa, S. Afr. J. Geol., 93, 664675, 1990.

Coetzee, H., and F. J. Kruger, Geochronology and Sr-isotope geochemistry of the Losberg Complex and the limits of Bushveld Complex magmatism, S. Afr. J. Geol., 92, 37-41, 1989.

Compston, W., and M. W. McElhinny, The Rb-Sr age of the Mashonaland dolerites of Rhodesia and its significance for palaeomagnetic correlation in southern Africa, Precambrian Res., 2, 305-315, 1975.

Cornell, D. H., Stratigraphy and petrography of the Hartley Basalt Formation, northern Cape Province, S. Afr. J. Geol., 90, 7-24, 1987.

Cornell, D. H., S. S. Schütte, and B. L. Eglington, The Ongeluk basaltic andesite formation in Griqualand West, South-Africa: Submarine alteration in a 2222 Ma Proterozoic sea, Precambrian Res., 79, 101-123, 1996.

Cornell, D. H., R. A. Armstrong, and F. Walraven, Geochronology of the Proterozoic Hartley Formation, South Africa: Constraints on the Kheis tectogenesis and the Kaapvaal Craton's earliest Wilson Cycle, J. Afr. Earth Sci., 26, 5-27, 1998

Dekkers, M. J., and J. H. Lindssen, Rockmagnetic properties of finegrained natural low-temperature haematite with reference to remanence acquisition mechanisms in red beds, Geophys. J. Int., 99, 1-18, 1989.

Doppelhammer, S. K., and R. B. Hargraves, Paleomagnetism of the Schuller and Franspoort kimberlite pipes in South Africa and an improved Premier pole, Precambrian Res., 69, 193-197, 1994.

Eriksson, S. C., Age of carbonatite and phoscorite magmatism of the Phalaborwa Complex (South Africa), Isot. Geosci., 2, 291-299(Chem. Geol., 46), 1984.

Eriksson, P. G., and B. F. F. Reczko, The sedimentary and tectonic setting of the Transvaal Supergroup floor rocks to the Bushveld complex, J. Afr. Earth Sci., 21, 487-504, 1995.

Evans, D. A. D., Early Paleoproterozoic glaciation in the context of Earth's first supercontinents, Geol. Soc. Am. Abstr. Programs, 31(7), 372, 1999

Evans, D. A., N. J. Beukes, and J. L. Kirschvink, Low-latitude glaciation in the Palaeoproterozoic Era, Nature, 386, 262-266, 1997.

Evans, D. A., R. L. Ripperdan, and J. L. Kirschvink, Cambrian drift of Gondwana: Plate tectonics or TPW?, J. Afr. Earth Sci., 27(1A), 67-69, 1998.

Fisher, N. I., T. Lewis, and B. J. J. Embleton, Statistical Analysis of Spherical Data, Cambridge Univ. Press, 1987.

Fisher, R. A., Dispersion on a sphere, Proc. R. Soc. London, Ser. A, 217, $295-305,1953$

Fourie, P. J., and D. H. de Jager, Phosphate in the Phalaborwa Complex, in Mineral Deposits of Southern Africa, vol. II, edited by C. R. Anhaeusser and S. Maske, pp. 2239-2253, Geol. Soc. S. Afr., Johannesburg, 1986.

Gibson, R. L., R. A. Armstrong, and W. U. Reimold, The age and thermal evolution of the Vredefort impact structure: A single-grain U-Pb zircon study, Inform. Circ. 309, 18 pp., Univ. Witwatersrand Econ. Geol. Res. Unit, Johannesburg, 1997.

Gough, D. I., A study of the palaeomagnetism of the Pilanesberg dykes., Mon. Not. R. Astron. Soc., Geophys. Suppl., 7, 196-213, 1956.

Gough, D. I., and C. B. van Niekerk, A study of the palaeomagnetism of the Bushveld Gabbro, Philos. Mag., Ser. 8, 4, 126-136, 1959.

Grobbelaar, W. S., and N. J. Beukes, The Bishop and Glosam manganese mines and the Beeshoek iron ore mine of the Postmasburg area, in Mineral Deposits of Southern Africa, vol. I, edited by C. R. Anhaeusser and S. Maske, pp. 957-961, Geol. Soc. S. Afr., Johannesburg, 1986.

Grobbelaar, W. S., M. A. Burger, A. I. Pretorius, W. Marais, and I. J. M. van Niekerk, Stratigraphic and structural setting of the Griqualand West and the Olifantshoek sequences at Black Rock, Beeshoek and Rooinekke Mines, Griqualand West, South Africa, Miner. Deposita, 30, 152-161, 1995.

Gulson, B. L., and M. T. Jones, Cassiterite: Potential for direct dating of mineral deposits and a precise age for the Bushveld Complex granites, Geology, 20, 355-358, 1992.

Gutzmer, J., and N. J. Beukes, Earliest laterites and possible evidence for terrestrial vegetation in the Early Proterozoic, Geology, 26, 263-266, 1998.

Hargraves, R. B., Paleomagnetic evidence relevant to the origin of the Vredefort Ring, J. Geol., 78, 253-263, 1970.

Hargraves, R. B., Palaeomagnetic and ${ }^{40} \mathrm{Ar} /{ }^{39} \mathrm{Ar}$ evidence for intrusion of dioritic and peralkaline rocks at Vredefort prior to overturning of the collar, S. Afr. J. Geol., 90, 305-313, 1987.

Hargraves, R. B., P. J. Hattingh, and T. C. Onstott, Palaeomagnetic results from the Timbavati Gabbros in the Kruger National Park, South Africa, S. Afr. J. Geol., 97, 114-118, 1994.
Hart, R. J., R. B. Hargraves, M. A. G. Andreoli, M. Tredoux, and C. M. Doucouré, Magnetic anomaly near the center of the Vredefort structure: Implications for impact-related magnetic signatures, Geology, 23, 277280, 1995.

Hattingh, P. J., The palaeomagnetism of the main zone of the eastern Bushveld Complex, Tectonophysics, 124, 271-295, 1986a.

Hattingh, P. J., The palaeomagnetism of the main zone in the western Bushveld Complex, Earth Planet. Sci. Lett., 79, 441-452, 1986b.

Hattingh, P. J., The palaeomagnetism of the Merensky Reef footwall rocks of the Bushveld Complex, Trans. Geol. Soc. S. Afr., 89, 1-8, 1986c.

Hattingh, P. J., Palaeomagnetism of the upper zone of the Bushveld Complex, Tectonophysics, 165, 131-142, 1989.

Hattingh, P. J., and N. D. Pauls, New palaeomagnetic results from the northern Bushveld Complex of South Africa, Precambrian Res., 69, 229-240, 1994

Hatton, C. J, and J. K. Schweitzer, Evidence for synchronous extrusive and intrusive Bushveld magmatism, J. Afr. Earth Sci., 21, 579-594, 1995.

Hoffman, P. F., and D. P. Schrag, Snowball Earth, Sci. Am., 282, 68-75, 2000.

Hoffman, P. F., A. J. Kaufman, G. P. Halverson, and D. P. Schrag, A Neoproterozoic snowball Earth, Science, 281, 1342-1346, 1998.

Holland, H. D., and N. J. Beukes, A paleoweathering profile from Griqualand West, South Africa: Evidence for a dramatic rise in atmospheric oxygen between 2.2 and 1.9 bybp, Am. J. Sci., 290-A, 1-34, 1990.

Hunter, D. R., and H. C. Halls, A geochemical study of a Precambrian mafic dyke swarm, Eastern Transvaal, South Africa, J. Afr. Earth Sci., 15, $153-168,1992$

Hunter, D. R., and D. L. Reid, Mafic dyke swarms in southern Africa, in Mafic Dyke Swarms, Geol. Assoc. Can. Spec. Pap., vol. 34, edited by H. C. Halls and W. F. Fahrig, pp. 445-456, 1987.

Jones, D. L., and M. W. McElhinny, Stratigraphic interpretation of paleomagnetic measurements on the Waterberg red beds of South Africa, J. Geophys. Res., 72, 4171-4179, 1967.

Jones, D. L., I. D. M. Robertson, and P. L. McFadden, A palaeomagnetic study of Precambrian dyke swarms associated with the Great Dyke of Rhodesia, Trans. Geol. Soc. S. Afr., 78, 57-65, 1975.

Kamo, S. L., W. U. Reimold, T. E. Krogh, and W. P. Colliston, A 2.023 Ga age for the Vredefort impact event and a first report of shock metamorphosed zircons in pseudotachylitic breccias and Granophyre, Earth Planet. Sci. Lett., 144, 369-387, 1996.

Karhu, J. A., and H. D. Holland, Carbon isotopes and the rise of atmospheric oxygen, Geology, 24, 867-870, 1996.

Kirschvink, J. L., The least-squares line and plane and the analysis of palaeomagnetic data, Geophys. J. R. Astron. Soc., 62, 699-718, 1980.

Kirschvink, J. L., E. J. Gaidos, L. E. Bertani, N. J. Beukes, J. Gutzmer, L. N. Maepa, and R. E. Steinberger, Paleoproterozoic Snowball Earth: Extreme climatic and geochemical global change and its biological consequences, Proc. Natl. Acad. Sci., U. S. A., 97, 1400-1405, 2000.

Kletetschka, G., P. J. Wasilewski, and P. T. Taylor, Unique thermoremanent magnetization of multidomain sized hematite: Implications for magnetic anomalies, Earth Planet. Sci. Lett., 176, 469-479, 2000.

Layer, P. W., A. Kröner, M. McWilliams, and N. Clauer, Regional magnetic overprinting of Witwatersrand Supergroup sediments, South Africa, J Geophys. Res., 93, 2191-2200, 1988.

Layer, P. W., M. Lopez-Martinez, A. Kröner, D. York, and M. McWilliams, Thermochronometry and palaeomagnetism of the Archaean Nelshoogte Pluton, South Africa, Geophys. J. Int., 135, 129-145, 1998.

Lu, G., C. McCabe, D. J. Henry, and A. Schedl, Origin of hematite carrying a Late Paleozoic remagnetization in a quartz sandstone bed from the Silurian Rose Hill Formation, Virginia, USA, Earth Planet. Sci. Lett., 126, 235-246, 1994.

Master, S., B. T. Verhagen, J. P. Bassot, N. J. Beukes, and S. Lemoine, Stable isotope signatures of Palaeoproterozoic carbonate rocks from Guinea, South Africa and Zimbabwe: Constraints on the timing of the ca. 2Ga "Lomagundi" del 13 C excursion, Ext. Abst. Early Proter. Symp., pp. 38-41, CIFEG Occas. Publ. 1993/23, Dakar, 1993.

McElhinny, M. W., Notes on progress in geophysics: Palaeomagnetic directions and pole positions-IX, Geophys. J. R. Astron. Soc., 16, 207-224, 1968.

McElhinny, M. W., and J. A. Cowley, Palaeomagnetic directions and pole positions-XV; Pole numbers $15 / 1$ to $15 / 232$, Geophys. J. R. Astron. Soc., $52,259-276,1978$

McElhinny, M. W., and P. L. McFadden, Paleomagnetism: Continents and Oceans, 386 pp., Academic, San Diego, Calif., 2000.

McElhinny, M. W., and N. D. Opdyke, The paleomagnetism of the Precambrian dolerites of eastern Southern Rhodesia, an example of geologic correlation by rock magnetism, J. Geophys. Res., 69, 2465-2475, 1964.

McElhinny, M. W., J. C. Briden, D. L. Jones, and A. Brock, Geological and geophysical implications of paleomagnetic results from Africa, Rev. Geophys., 6, 201-238, 1968 . 
McFadden, P. L., and M. W. McElhinny, The combined analysis of remagnetization circles and direct observations in palaeomagnetism, Earth Planet. Sci. Lett., 87, 161-172, 1988

McFadden, P. L., and M. W. McElhinny, Classification of the reversal test in palaeomagnetism, Geophys. J. Int., 103, 725-729, 1990.

Miyano, T., and N. J. Beukes, Phase relations of stilpnomelane, ferriannite and riebeckite in very low-grade metamorphosed iron-formations, Trans. Geol. Soc. S. Afr., 87, 111-124, 1984.

Moen, H. F. G., The Kheis Tectonic Subprovince, southern Africa: A lithostratigraphic perspective, S. Afr. J. Geol., 102, 27-42, 1999.

Morgan, G. E., The paleomagnetism and cooling history of metamorphic and igneous rocks from the Limpopo Mobile Belt, southern Africa, Geol. Soc. Am. Bull., 96, 663-675, 1985.

Morgan, G. E., and J. C. Briden, Aspects of Precambrian palaeomagnetism, with new data from the Limpopo mobile belt and Kaapvaal craton in southern Africa, Phys. Earth Planet. Inter., 24, 142-168, 1981.

Mushayandebvu, M. F., D. L. Jones, and J. C. Briden, Palaeomagnetic and geochronological results from Proterozoic mafic intrusions in southern Zimbabwe, in Physics and Chemistry of Dykes, edited by G. Baer and A. Heimann, pp. 293-303, A. A. Balkema, Brookfield, Vt., 1995.

Ohmoto, H., Evidence in pre-2.2 Ga paleosols for the early evolution of atmospheric oxygen and terrestrial biota, Geology, 24, 1135-1138, 1996.

Onstott, T. C., R. B. Hargraves, and P. Joubert, Constraints on the tectonic evolution of the Namaqua Province, II, Reconnaissance palaeomagnetic and ${ }^{40} \mathrm{Ar} /{ }^{39} \mathrm{Ar}$ results from the Namaqua Province and Kheis Belt, Trans. Geol. Soc. S. Afr., 89, 143-170, 1986a.

Onstott, T. C., R. B. Hargraves, P. Joubert, and D. L. Reid, Constraints on the tectonic evolution of the Namaqua Province, I, Palaeomagnetic and ${ }^{40} \mathrm{Ar}{ }^{39} \mathrm{Ar}$ results from the Richtersveld Subprovince, Trans. Geol. Soc. S. Afr., 89, 117-142, 1986b.

Partridge, T. C., and R. R. Maud, Geomorphic evolution of southern Africa since the Mesozoic, S. Afr. J. Geol., 90, 179-208, 1987.

Piper, J. D. A., The palaeomagnetism of Precambrian igneous and sedimentary rocks of the Orange River belt in South Africa and South West Africa, Geophys. J. R. Astron. Soc., 40, 313-344, 1975.

Reischmann, T., Precise U/Pb age determination with baddeleyite ( $\mathrm{ZrO} 2)$, a case study from the Phalaborwa Igneous Complex, South Africa, S. Afr. J. Geol., 98, 1-4, 1995.

Rye, R., and H. D. Holland, Paleosols and the evolution of atmospheric oxygen: A critical review, Am. J. Sci., 298, 621-672, 1998.

Schmidt, P. W., and D. A. Clark, Palaeomagnetism and magnetic anisotropy of Proterozoic banded iron-formations and iron ores of the Hamersley Basin, Western Australia, Precambrian Res., 69, 133-155, 1994.
Stowe, C. W., The Upington geotraverse and its implications for craton margin tectonics, in Namaqualand Metamorphic Complex, Spec. Publ. Geol. Soc. S. Afr., vol. 10, edited by B. J. V. Botha, pp. 147-171, Johannesburg, 1983 .

Taylor, G., R. A. Eggleton, C. C. Holzhauer, L. A. Maconachie, M. Gordon, M. C. Brown, and K. G. McQueen, Cool climate lateritic and bauxitic weathering, J. Geol., 100, 669-677, 1992.

Thomas, M. F., Geomorphology in the Tropics: A Study of Weathering and Denudation in Low Latitudes, 460 pp., John Wiley, New York, 1994.

Van der Voo, R., The reliability of paleomagnetic data, Tectonophysics, 184 , $1-9,1990$.

Van Schalkwyk, J. F., and N. J. Beukes, The Sishn iron ore deposit, Griqualand West, in Mineral Deposits of Southern Africa, Geol. Soc. S. Afr., vol. I, edited by C. R. Anhaeusser and S. Maske, pp. 931-956, Johannesburg, 1986.

Van Wyk, J. P., The geology of the area Rooinekke-Matsap-Wolhaarkop in Northern Cape with special reference to the Koegas Subgroup, Transvaal Supergroup, unpublished M.Sc. thesis, 159 pp., Rand Afrikaans Univ., Johannesburg, 1980

Walraven, F., and E. Hattingh, Geochronology of the Nebo Granite, Bushveld Complex, S. Afr. J. Geol., 96, 31-41, 1993.

Walraven, F., R. A. Armstrong, and F. J. Kruger, A chronostratigraphic framework for the north-central Kaapvaal craton, the Bushveld Complex and the Vredefort structure, Tectonophysics, 171, 23-48, 1990.

Wiggering, H., and N. J. Beukes, Petrography and geochemistry of a 2000-2200-Ma-old hematitic paleo-alteration profile on Ongeluk basalt of the Transvaal Supergroup, Griqualand West, South Africa, Precambrian Res., 46, 241-258, 1990.

Wilson, J. F., D. L. Jones, and J. D. Kramers, Mafic dyke swarms of Zimbabwe, in Mafic Dyke Swarms, Geol. Assoc. Can. Spec. Pap. 34, edited by H. C. Halls and W. F. Fahrig, pp. 433-444, 1987.

Wingate, M. T. D., A palaeomagnetic test of the Kaapvaal-Pilbara (Vaalbara) connection at $2.78 \mathrm{Ga}$, S. Afr. J. Geol., 101, 257-274, 1998.

N. J. Beukes, Department of Geology, Rand Afrikaans University, Auckland Park 2006, Johannesburg, South Africa. (njb@rau3.rau.ac.za)

D. A. D. Evans, Department of Geology and Geophysics, Yale University, New Haven, CT 06520-8109, USA. (dai.evens@yale.edu)

J. L. Kirschvink, Division of Geological and Planetary Sciences, 17025, California Institute of Technology, Pasadena, CA 91125, USA (kirschvink@caltech.edu) 